\title{
Arte Nova e Eclectismo no palacete projectado por Ernesto Korrodi para a família Bouhon
}

\author{
Ana Mónica Pereira Reis de Matos \\ Romãozinho ${ }^{1}$
}

RESUMO: No início do século XX, o design de interiores resultava do trabalho desenvolvido por arquitectos, decoradores, pintores ou entalhadores. Embora então integrado no universo das artes decorativas, acreditamos que já existia como prática profissional regulada por uma rede coerente de princípios de concepção e pelo entendimento do espaço interior como teia global de relações que se estabelece entre planos, ornamento, iluminação e mobiliário. No final do século anterior, perante a necessidade de proceder a uma reforma do ensino industrial, o governo português abrira um concurso para contratação de professores estrangeiros. Evidenciamos o papel de Ernesto Korrodi (1870-1944). As suas obras decorrem de uma atitude paradoxalmente ecléctica e moderna, apoiando-se por um lado, numa reinterpretação de soluções referenciadas no período medieval ou na Renascença; por outro, em fórmulas sediadas nos movimentos Arts and Crafts, Arte Nova (Art Nouveau) ou Secessão. Nos seus projectos persistem determinadas dependências e hierarquias, mas estas se cruzam com as necessidades despertadas pelas inovações técnicas, o que faz com que se preocupe também com a resposta à eclosão de novas funções e mobiliário na casa, a par das exigências higienistas do momento. $\bigcirc$ presente artigo consiste na análise da casa da família Bouhon, localizada na cidade da Covilhã, Portugal. Se a Arte Nova marca as suas fachadas, no interior deparamo-nos com espaços mais depurados, marcados por apontamentos decorativos, incorporados na azulejaria e nos tectos estucados ou em caixotões. $O$ ornamento contribui, deste modo, para a dignificação dos planos das paredes, lambris e tectos, assumindo um papel fundamental na composição espacial.

PALAVRAS-CHAVE: Arte Nova (Art Nouveau). Design de Interiores. Eclectismo. Funcionalidade. Ornamento. Portugal.

ABSTRACT: In the early twentieth century, Interior Design resulted from the work of architects, decorators, painters and carvers. Although then integrated into the world of decorative arts, we believe that already existed as a profession regulated by a coherent network design principles and the understanding of interior space as global web of relationships established between plans, ornament, lighting and furniture solutions. At the end of the previous century, before the need for a reform of industrial training, the Portuguese Government opened a tender for hiring of foreign teachers. We emphasize
1. Licenciada em Arquitectura, Mestre e Doutorada em Design pela Faculdade de Arquitectura da Universidade Técnica de Lisboa; docente da Escola Superior de Artes Aplicadas do Instituto Politécnico de Castelo Branco. Integra desde 2009 a rede internaciona 1 de investigadores Réseau Art Nouveau Network. E-mail: <monica.romaoz@gmail. com>. 
2. Cf. Rui Afonso Santos (1995, p.144).

3. Cf. Maria João Rocha Simões Fernandes (1985, p.43). the role of Ernesto Korrodi (1870-1944). His works arise from an attitude paradoxically modern and eclectic, leaning one hand on a reinterpretation of solutions referenced in the medieval period or the Renaissance, on the other, based on formulas from Arts and Crafts movement, Art Nouveau or Secession. In his projects certain rooms and hierarchies remain, but these are intersect with the needs aroused by technical innovations, which causes an attempt to answer to the emergence of new functions and features in the house, along with the hygienists demands of the moment. This article consists in the analysis of Bouhon home, located in the city of Covilhã, Portugal. If Art Nouveau is visible in the elevations, inside we find a cleaner space, marked by decorative notes which we can find in tiles and embedded in the stucco or coffered ceilings. The ornament thus contributes to the dignity of the walls, wainscots and ceiling plans, assuming a key role in the spatial composition.

KEYWORDS: Art Nouveau. Interior Design. Eclecticism. Functionality. Ornament. Portugal.

Introdução

No final do século XIX, a procura de originalidade dependia da composição mais ou menos inventiva criada a partir de vocabulários de estilos anteriores e, consoante o cliente, o lugar e restantes condicionantes programáticas, - projecto poderia seguir uma linguagem Renascença (revivalismo sobretudo abraçado pela Inglaterra e Alemanha), próxima aos modelos de Luís XV ou Luís XVI, neo-românica e cada vez mais raramente neo-manuelina ou neo-gótica à medida que avançamos no séc. XX. As obras associadas à Arte Nova (Art Nouveau), assinalam o início de um processo de viragem, simbolizando uma ruptura com um século XIX, marcado por imitações e formas estrangeiradas, em que as "as artes menores caminhavam ao acaso, hesitantes entre o tradicionalismo estafado [os chamados "estilos históricos"] e um mal disciplinado naturalismo"2.

Observa-se então, em Portugal, uma atitude projectual diferenciada consoante a formação académica de cada arquitecto, decorador, pintor ou entalhador. Se por exemplo, Ventura Terra (1866-1919), Norte Júnior (1 878-1962) ou Adães Bermudes (1 864-1947) estudaram em França, já Raul Lino (1879-1974) ou Ernesto Korrodi (1 870-1944) fizeram um percurso afastado dos modelos franceses. De acordo com Maria João Fernandes, num núcleo de carácter mais erudito encontraremos José Coelho, Miguel Nogueira, Adães Bermudes, Norte Júnior, Ernesto Korrodi e Ventura Terra, "que a par de exemplos de arquitectura historicista produziram obras marcadas pela nova estética Arte Nova segundo a particular expressão de cada"; e acrescenta ainda a este grupo autores consagrados na região de Aveiro, como José de Pinho, Jaime Inácio dos Santos e Francisco Augusto da Silva Rocha (1864-1957)33. Parece-nos, contudo, pertinente acrescentar que alguns destes autores "de carácter mais erudito", nomeadamente Ernesto Korrodi e Raul Lino, combinaram nas suas arquitecturas uma linguagem chã mais portuguesa marcada por soluções tradicionais da arquitectura portuguesa e por apontamentos Arte Nova mais sintetizados que os aproximam de uma Arte Nova inglesa e/ou Secessão vienense e do espírito da corrente Arts and Crafts sobretudo no caso do design de interiores.

Por outro lado, a difusão dos princípios e conceitos proclamados por movimentos internacionais seria reforçada pelo contributo dos arquitectos e 
decoradores estrangeiros que se instalaram em Portugal no final do século XIX, na sequência do concurso para contratação de professores estrangeiros, promovido pelo Governo Português. $\bigcirc$ processo de análise de estudos nacionais sobre a temática Arte Nova e a consulta de imprensa e de documentação dos Arquivos Municipal e Distrital de Leiria, levou-nos a constatar que os interiores domésticos projectados por Ernesto Korrodi, arquitecto e designer de origem suíça, contratado para leccionar no ensino industrial, constituíam fontes de análise não exploradas. $\bigcirc$ seu percurso e obra arquitectónica foram primeiramente analisados nos estudos pioneiros intitulados Ernesto Korrodi: 1889-1944: arquitectura, ensino e restauro do património 4 e Rota de arquitectura Korrodi: contributo para o conhecimento da vida e obra do arquitecto (1870-1944)5. Em 1889, Korrodi seria colocado na Escola Industrial de Braga e mais tarde, em 1894, na Escola Domingos Sequeira, em Leiria, onde foi professor da disciplina de Desenho Ornamental e Modelação. Ernesto Korrodi nascera em Zurique em 30 de Janeiro de 1870 e, aos quinze anos, ingressara na Escola de Arte Industrial, onde concluiu os cursos de escultor-decorador e de professor de desenho6. Em 1898, publicou um primeiro estudo intitulado Estudos de Reconstrucção sobre o Castello de Leiria: Reconstituição graphica de um notável exemplo de construcção civil e militar portuguesa ${ }^{7}$, graças aos quais the seria atribuído, sob a proposta do Ministro e Secretário de Estado das Obras Públicas, Comércio e Indústria, o título de Comendador da Real Ordem do Mérito Civil. Em 1905, Korrodi foi nomeado director interino da Escola Domingos Sequeira e, em 1906, assumiu a direcção efectiva da escola, cargo que exerceu até 1917. No mesmo ano, montou uma oficina de cantaria junto à sua casa de Leiria, a Villa Hortênsia, que oferecia cantarias de calcário e lioz. Projectou obras para todo o país: Paços de Concelho, Sedes de Bancos, Garagens, Hotéis, Prédios de Rendimento e Habitações Unifamiliares. Duas obras da sua autoria receberiam o Prémio Valmor: a Casa do Dr. António Macieira (Avenida Fontes Pereira de Melo, Lisboa) em 1910 e o Prédio de Rendimento da viúva Estefânia Macieira (Rua Viriato, Lisboa) em 1917. Em 1926, foi-the atribuído o Diploma de Arquitecto pela Escola de Belas Artes de Lisboa.

As suas obras revelam-nos, por um lado, registos apoiados numa reinterpretação de soluções referenciadas no período medieval ou na Renascença, por outro fórmulas sediadas nos movimentos Arts and Crafts ou Proto-Arte Nova ${ }^{8}$, Arte Nova e Secessão vienense ${ }^{9}$. Korrodi assinava revistas da especialidade, nomeadamente a Academy Architecture and Annual Architectural Review 11895 1922) ou a Schweizerishe Bauzeitung (1900-1935), veículos difusores daquilo que se passava lá fora ${ }^{10}$. Os seus estudos arqueológicos permitiram-lhe criar obras particularmente fundamentadas sob o ponto de vista do léxico decorativo nacional e do uso cuidado de materiais e técnicas tradicionais ${ }^{11}$. Algumas das suas obras, representativas da influência da corrente Arte Nova em Portugal, não tinham sido visitadas ou estudadas e, neste sentido, pretendemos demonstrar, por meio da leitura de um estudo de caso inédito, que a sua atitude projectual, essencialmente ecléctica, denuncia um sentido de modernidade, presente em apontamentos decorativos sua
4. Ver Lucília Verdelho da Costa (1997).

5. Ver Maria Genoveva Moreira Oliveira (2005).

6. Ver Sousa Viterbo (1899, p.46).

7. "Contém 26 estampas, de $\mathrm{r}$ e p r o d u c ç õ e s photolithographicas dos desenhos originaes (plantas, perspectivas, apontamentos do estado actual, etc)", cf. carta autobiográfica de Ernesto Korrodi, apud Sousa Viterbo (1899, p.47).

8. Em meados de 1850 , alguns artistas ingleses pretenderiam a renascença de uma arte mais próxima do gótico e dos primitivos. Para John Ruskin (18191900), o teórico do movimento Arts and Crafts, as descobertas científicas $\mathrm{e}$ industriais seriam a causa da decadência artística. Avanços tecnológicos como os caminhos-de-ferro e os telégrafos eram inimigos do progresso no âmbito da produção criativa. Mas um dos contributos inegáveis seria a criação de corporações do tipo medieval, à cabeça das quais surgiriam operários excepcionais tais como William Morris e Walter Crane (1845-1915). Madsen (1923-2007) defende precisamente que a Arte Nova apareceu em Inglaterra e atribuí-lhe a designação de Proto-Art Nouveau, no fundo uma derivação do movimento Arts and Crafts com ênfase na decoração linear e floral. Ver S. Tschudis Madsen (1967, p.14).

9. Em França, entre 1890 e 1900 , toda uma geração de designers arquitectos ou escultores lançava-se no aprofundamento de novas soluções no âmbito do Design: Tony Selmersheim (1871-1971), Charles Plumet (1861-1928), Hector Guimard (1867-1942), 
Eugène Gaillard (18621933), George de Feure (1868-1943), Eugène Colonna, Alexandre Charpentier (1859-1909), entre outros. Émile Gallé (1846-1904) impulsionava este novo movimento a partir da procura de elementos de inspiração renovada na natureza, a Art Nouveau. Na Bélgica, destacava-se a experimentação formal desenvolvida por Victor Horta (1861-1947), Paul Hankar (1859-1901), Gustave Serrurier-Bovy (1858-1910) e Henry Van de Velde (1863-1957). Por fim, na Áustria, no âmbito da Secessão vienense, explorava-se um estilo rectilíneo e apesar de incorporar elementos essenciais da Art Nouveau, a sua repulsa face à ornamentação opõe-se inteiramente ao espírito desta corrente, conduzindo a uma abstracção crescente dos próprios motivos que integravam o design de interiores e respectivo mobiliário e abrindo o caminho ao movimento modernista; destacam-se Otto Wagner (1841-1918), Joseph Hoffmann (18701956), Adolf Loos (18701933) e Joseph Olbrich (1867-1908).

10. Ver Lucília Verdelho da Costa (1997, p.302).

11. Ver, José Manuel Pedreirinho (1981, p. 60).

12. Ver Ana Mónica Romãozinho (2013).

13. Informação cedida pelo Eng. ${ }^{\circ}$ Miguel Korrodi, bisneto de Ernesto Korrodi. autoria, soluções industriais, novas funcionalidades e espacialidades mais fluídas, resultante da influência exercida pelos padrões estéticos e funcionais propagados quer pela imprensa internacional quer por obras literárias de referência ${ }^{12}$.

No âmbito do presente estudo, evidenciamos não só a literatura relevante, como o trabalho de campo, possível graças à disponibilidade da família Carneiro (actuais proprietários) e a elaboração de uma ficha analítica de projecto no âmbito da qual procedemos a uma sistematização do levantamento fotográfico e análise escrita/desenhada das soluções ornamentais, construtivas e de mobiliário. Estamos perante uma tipologia de habitação unifamiliar situada na Covilhã, centro industrial então em franca expansão e resultado de uma encomenda por parte do belga Joseph Bouhon, proprietário da Fábrica do Sineiro. Korrodi conheceu Bouhon em 1895, pois Frida Korrodi, a irmã mais velha de Ernesto, casara-se com Camille Bouhon (1872-1952), irmão de Joseph e químico que trabalhava numa fábrica de tecidos na Covilhã ${ }^{13}$. Por sua vez, a filha de Joseph Bouhon, Susana (1908-1991), casar-se-ia em 1929 com Ernesto Camilo Korrodi (1905-1985), filho de Ernesto Korrodi, também arquitecto (Figura 1).

A casa da família Bouhon terá sido projectada entre 1919 e 1922. A fachada revela a influência exercida pelos modelos renascentistas, embora nem



Figura 1 - Vista da fachada principal do palacete. Fotografia de Mónica Romãozinho. 
todos os vãos sigam alinhamentos rígidos: o aparelho rusticado do soco, a demarcação dos pisos através de frisos de pedra, as cantarias dos vãos simples ou tripartidos com os seus medalhões. No entanto, são notáveis os apontamentos Arte Nova que vêm ritmar a composição destes planos exteriores: o recurso a arcos abatidos com remates em voluta presentes na varanda de ângulo, no medalhão da janela do salão ou no vão tripartido da sala de almoços orientada a tardoz; o arqueamento de alguns lintéis; os planos de azulejaria com rosas damascenas e caules em movimento ou rostos femininos emoldurados por cercaduras como os mesmos motivos, sempre em tonalidades pastel. A serralharia artística surge também inspirada na natureza, mas de modo mais sintetizado, obedecendo, contudo, a uma composição simétrica. As fachadas encontram-se revestidas a ladrilho branco e o coroamento a ladrilhos cor marfim e preto, dispostos de modo alternado. Ao longo desta faixa final, os ladrilhos pretos formam cruzes que recebem azulejos Arte Nova com acantos de contorno linear. Toda a azulejaria que reveste o exterior terá sido importada da Bélgica ${ }^{14}$. As soluções afastam-se aqui de uma arquitectura de raízes portuguesas e, deste modo, Korrodi enfatiza a vertente mais internacional desta obra, em resposta ao gosto do cliente belga que se enquadrava numa burguesia emergente. Contudo, é-nos impossível tipificar o seu perfil de cliente, pois o mesmo autor projectou para industriais e estrangeiros como é o caso, além de comerciantes, políticos (António Macieira, por exemplo), médicos (Egas Moniz, a quem seria atribuído um Prémio Nobel pelas suas descobertas no campo da neocirurgia), entre outros clientes portugueses, sendo a influência da Arte Nova transversal a muitas destas encomendas independentemente da nacionalidade do cliente.

$\mathrm{Na}$ perspectiva da sua volumetria arquitectónica, constatamos que a casa Bouhon projecta-se numa planta em forma de " $\mathrm{L}$ ", destacando-se dois volumes salientes: a varanda com o pequeno alpendre e a bow-window. Existe uma separação clara entre esfera social e privada da casa que apresenta quatro pisos: sub-cave (garagem, lavagem de carros e garrafeira); cave (bilhar, armazéns, cozinha e dependências complementares); rés-do-chão (funções de recepção e convívio familiar); primeiro andar (quartos da família e de hóspedes) e último piso em águas furtadas (alojamento do pessoal doméstico e da preceptora). Os próprios acessos verticais permitem a separação no âmbito da circulação de pessoal doméstico e da própria família.

As plantas desenhadas denunciam a influência que os modelos clássicos exercem não só ao nível das volumetrias sólidas e bem definidas, mas também na definição de uma geometria reguladora de todo o projecto. Korrodi explora mais uma vez estratégias históricas de composição espacial como a axialidade e a simetria, respondendo às exigências funcionais e programáticas (Figura 2).

$\bigcirc$ hall é definido como espaço gerador da casa, apresentando uma forma octogonal, seccionada no piso de recepção e completa no piso privado, que se aproxima dos modelos do Renascimento italiano. A entrada faz-se através de um pequeno vestíbulo (Figura 3) que integra uma escadaria de acesso ao hall de distribuição. Este projecto difere de todos os outros não só esteticamente mas também
14. "Korrodi pôde dar provas do seu entendimento graças à encomenda de um estrangeiro - como ele também o era, afinal -, que para a sua moradia mandou vir da Bélgica os azulejos dos painéis decorativos das paredes, de estilizações Arte Nova"; cf. Lucília Verdelho da Costa (1997, p.282). 


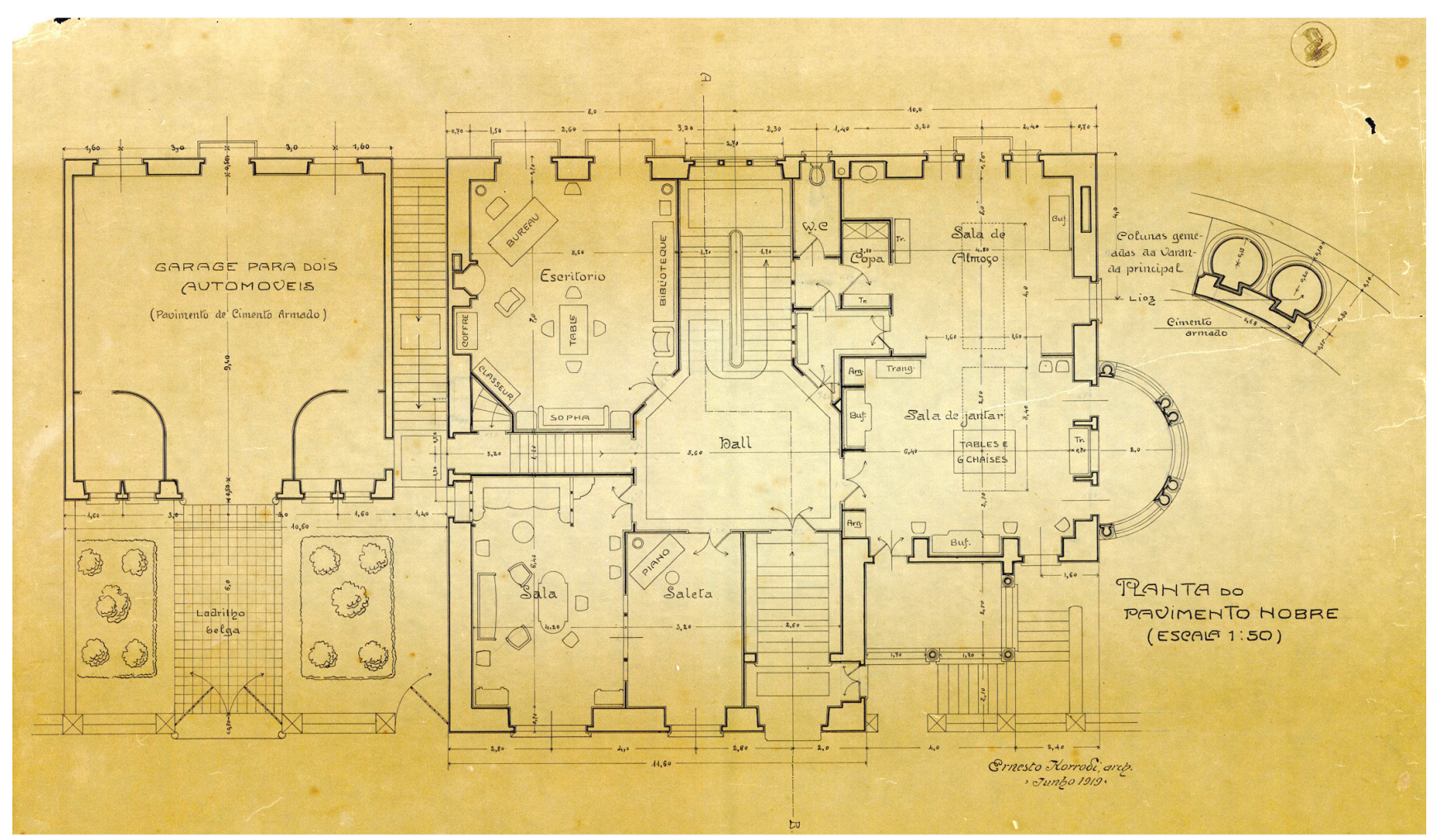

Figura 2 - Planta do piso térreo. Acervo do Arquivo Distrital de Leiria.

ao nível funcional e o vestíbulo é exemplo disso, pois apresenta uma pequena porta lateral que conduz a uma escada exterior de serviço que dá acesso à rouparia. Debaixo do tapete que antecede a escadaria, encontra-se um alçapão onde era largada a lenha, para depois ser recolhida ao nível da cave e transportada para o respectivo compartimento. $\bigcirc$ vestíbulo encontra-se ainda hoje pintado de azul petróleo, que contrasta com o lambril e o tecto claro em cor marfim.

$\bigcirc$ tratamento do tecto reporta-se essencialmente ao estilo Luís XVI, pela sua cor mas também pelos apontamentos dourados e léxico decorativo como os acantos visíveis nas mísulas e as molduras com óvulos e dardos, embora o centro se apresente pintado de azul, enfatizando a leitura do lampião que segue o mesmo estilo. Uma faixa de papel com rosas vermelhas e folhas de louro estilizadas, atadas por fitas, antecede a cornija. Os caixotões apresentam faixas de papel com rosas, caules e folhas estilizadas em cores esbatidas (rosa e verde) sobre fundo dourado, que correspondem a apontamentos Arte Nova, também visíveis ao nível do lambril, que apresenta superiormente vasos com rosas e acantos, executados em estuque e pintados de creme. A verticalidade surge acentuada pelas pilastras pintadas de verde, que acabam por ritmar o lambril e que estabelecem uma relação de continuidade com as ombreiras e lintéis das portas, da mesma cor. $\bigcirc$ desenho da porta encontra-se sediado numa linguagem Renascença, pelo seu traçado rectilíneo, pela canelura das suas ombreiras, pelo seu lintel que se eleva sob a forma de frontão 
rectangular, pelo jogo geométrico formado pelos pinázios que se traduz numa composição de quadrados e quadrados chanfrados.

Na casa Bouhon, o hall (Figura 4) não apresenta uma vocação como espaço de permanência e a sua linguagem compensa a maior exuberância habitualmente presente nas salas ou salões, à semelhança do que era aconselhado em certos manuais e tratados de savoir vivre, publicados na França no mesmo período: "(...) é aqui que ocorrem os empregados a fim de receberem as ordens dos donos ou para anunciarem as visitas; a sua decoração é geralmente sóbria e severa" ${ }^{\prime 15}$. Nesta altura, estes espaços adoptavam frequentemente cânones estéticos da Renascença ou do Gótico e a primeira tendência é observável neste caso, ao nível do tecto com os seus caixotões, do lambril com as suas pilastras, das portas e respectivos puxadores, assim como dos próprios pavimentos. Motivos florais marcam cada um dos caixotões de fundo azul do tecto, sob a forma de festões que estabelecem uma ligação visual entre os vários apainelados e que surgem animados por rosas e fitas entrelaçadas em movimento. Estes apainelados surgem emoldurados por frisos com óvulos e dardos, dando continuidade à solução adoptada na pequena antecâmara.

caixotão central, demarcado nos seus cantos por pinhas salientes, reveste-se de particular valor simbólico, apresentando três cartelas emolduradas por
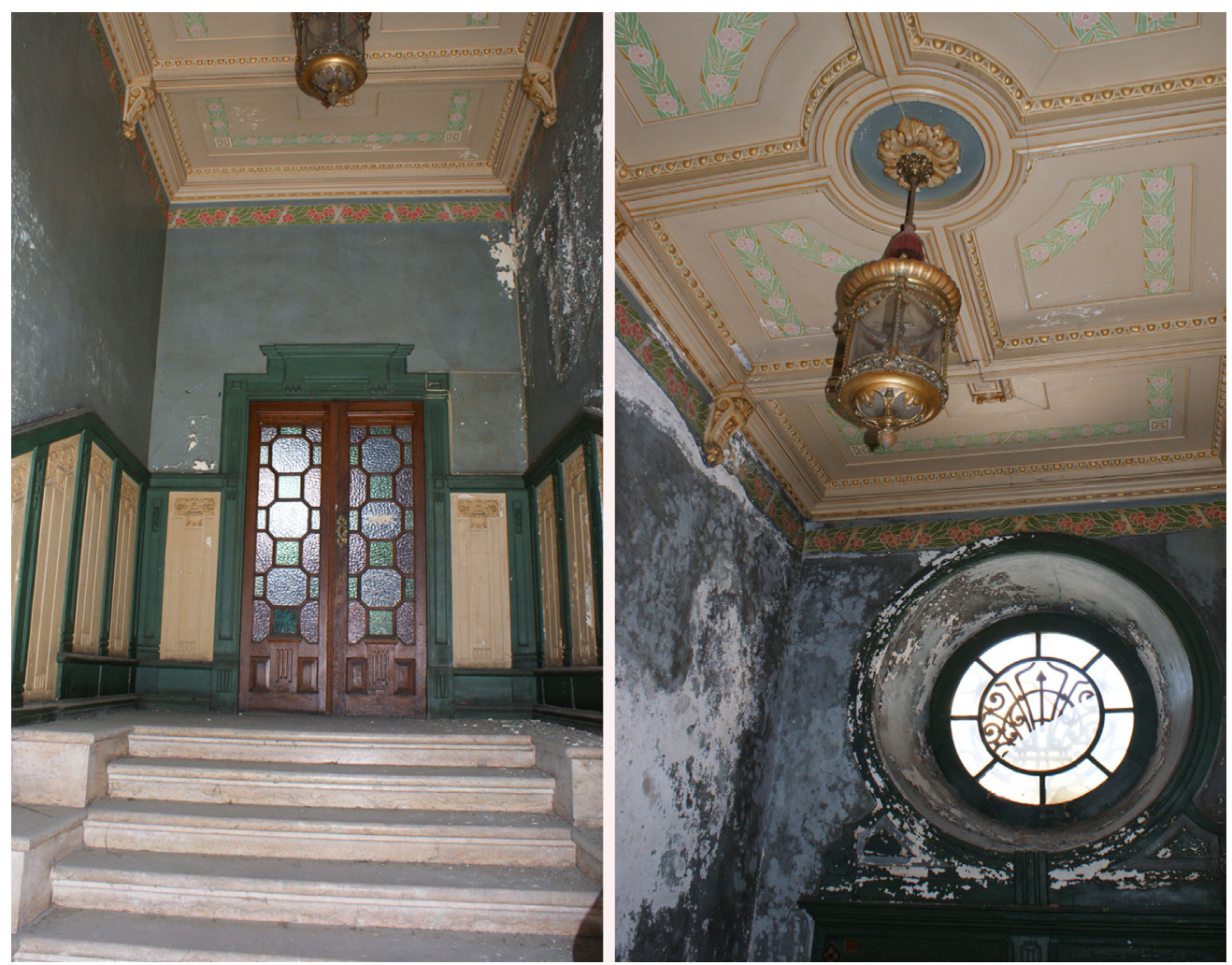

Figura 3 - Vestíbulo de chegada: vista da escada e porta de acesso ao hall; pormenor do óculo com serralharia Arte Nova e tecto. Fotografias de Mónica Romãozinho.
15. “(...) là que se tiennent les domestiques pour répondre aux ordres de leurs maîtres ou pour annoncer les visiteurs; sa décoration est généralement sobre et sévère. (...)"; cf. Ris-Paquot (1894, p.194). 
16. Símbolo de vitória, de ascensão, da imortalidade da alma: "É o que acontece com o ramo de ouro de Eneias e com os mistérios de Elêusis; com o salgueiro chinês, com o sakaki japonês; com a acácia maçónica; com o visco druídico; com, mais uma vez, os ramos de Salgueiro, de que fala o Pastor de Hermas; com o buxo que em França se planta nos túmulos no domingo de Ramos. As palmas de Ramos prefiguram a Ressurreição de Cristo, após o drama do calvário (...) A coroa de espinhos de Cristo teria sido entrançada com espinhos de acácia. Por fim, no ritual maçónico, um ramo de acácia é colocado sobre o manto do recipiendário, para recordar aquele que foi plantado no túmulo do Hirão."; cf. Jean Chevalier e Alain Cheerbrandt (1994, p.37, 502).

17. Joseph estudou até aos 16 anos num colégio na Bélgica, de onde regressou para a Covilhã com o curso de tintureiro. Tanto ele como o irmão Camille estudaram em Liège e em vários documentos são descritos como "Quimicos". Em Dezembro de 1921 houve um incêndio na fábrica e Joseph morreu de ataque cardíaco, tendo sido a casa posteriormente vendida ao Dr.Fernando Carneiro. Informações cedidas pelo Eng. ${ }^{\circ}$ Miguel Korrodi, bisneto de Korrodi e de Joseph Bouhon.

18. Encontrámos um exemplo similar da marca Gilliot Hemiksen, pertencente a uma casa próxima de Namur na Bélgica. C.1910. Disponível em: http://www. theantiquefloorcompany. com. Acesso em: 11 ago. 2011. coroas entrelaçadas, lendo-se na cartela central AD. Gloria Belgivm. Anno Domini. MCMXXIII e nas laterais Labor e Honor, mensagens respectivamente complementadas pelas imagens de um fuso e de uma palma, também conhecida como acácia maçónica ${ }^{16}$, símbolo da imortalidade. $\bigcirc$ fuso constitui uma referência simbólica à profissão de Joseph Bouhon, ligada aos lanifícios ${ }^{17}$. A cornija revela um trabalho de entalhe rigoroso e apresenta um friso de contas douradas. Acantos, volutas e rosas seguem movimentos assimétricos. Um friso de papel, com rosas abertas, destaca-se sobre o azul das paredes. No desenho técnico respeitante à Decoração do hall, a decoração geométrica seria executada em estuque a imitar madeira e constituída por pequenos motivos quadrados idênticos aos do papel da sala de jantares.

$\bigcirc$ lambril que percorre todo o hall surge revestido a papel oleado com relevo, eventualmente proveniente da fábrica britânica Lincrusta, ainda hoje existente. A primeira opção teria correspondido a um trabalho de estuque a imitar madeira, de acordo com o desenho respeitante à decoração do hall. É importante relembrar que o período vitoriano alimentara toda uma indústria de produção de revestimentos decorativos. A planta de pavimentos, em mosaico cerâmico e de origem certamente belga, desdobra-se em dois tapetes, o central que se inscreve na forma poligonal, e outro, de configuração rectangular, que antecede o lance de escadas de acesso ao piso inferior.

pavimento central, idêntico ao do vestíbulo de entrada, é constituído por mosaicos quadrados com padrão formado por folhas e volutas que obedecem a uma simetria absoluta, ao mesmo tempo em que simulam mosaicos romanos de pequena escala e formato irregular. Uma rica cercadura, constituída por três frisos, remata esta composição, apresentando na faixa central mosaicos similares com volutas e, nos frisos de menor espessura, um jogo de linhas curvas e contracurvas. No tapete que demarca o arranque da escadaria, observamos uma composição central idêntica à anterior, emoldurada por um friso igual aos menos espessos da composição anterior. À volta deste tapete, sucedem-se mosaicos com o padrão de uma estrela e formas quadrifoliadas. As cores dominantes são a terracota, sanguede-boi, verde e marfim. Este mesmo pavimento cerâmico pode ter sido importado da Bélgica, pois a fábrica Gilliot Hemiksen produzia padrões similares ${ }^{18}$.

As portas do hall apresentam novamente frontões estilo Renascença, mas neste caso com remates laterais curvos, revelando festões que pendem verticalmente ao longo das suas folhas ou em arco no caso dos frontões, assim como conchas explodidas, elementos que surgem evidenciados pelo Rococó e que persistiriam no período de Luís XVI. Os puxadores em bronze remetem-nos para o período Barroco, com os seus movimentos ondulantes, conchas explodidas, acantos, uma pequena flor no remate inferior, mas ainda dominados pela simetria. $\bigcirc$ manípulo da porta da antecâmara diferencia-se dos outros pelo jogo de cubos, paralelepípedos, discos e elementos esféricos.

Todas as portas que confinam com o hall seriam pormenorizadas no respectivo mapa de vãos (Figura 5), elaborado à escala 1:10 (versão inicial datada de 1920). Apresentam-se neste mapa quatro modelos de porta: tipo A (porta para 

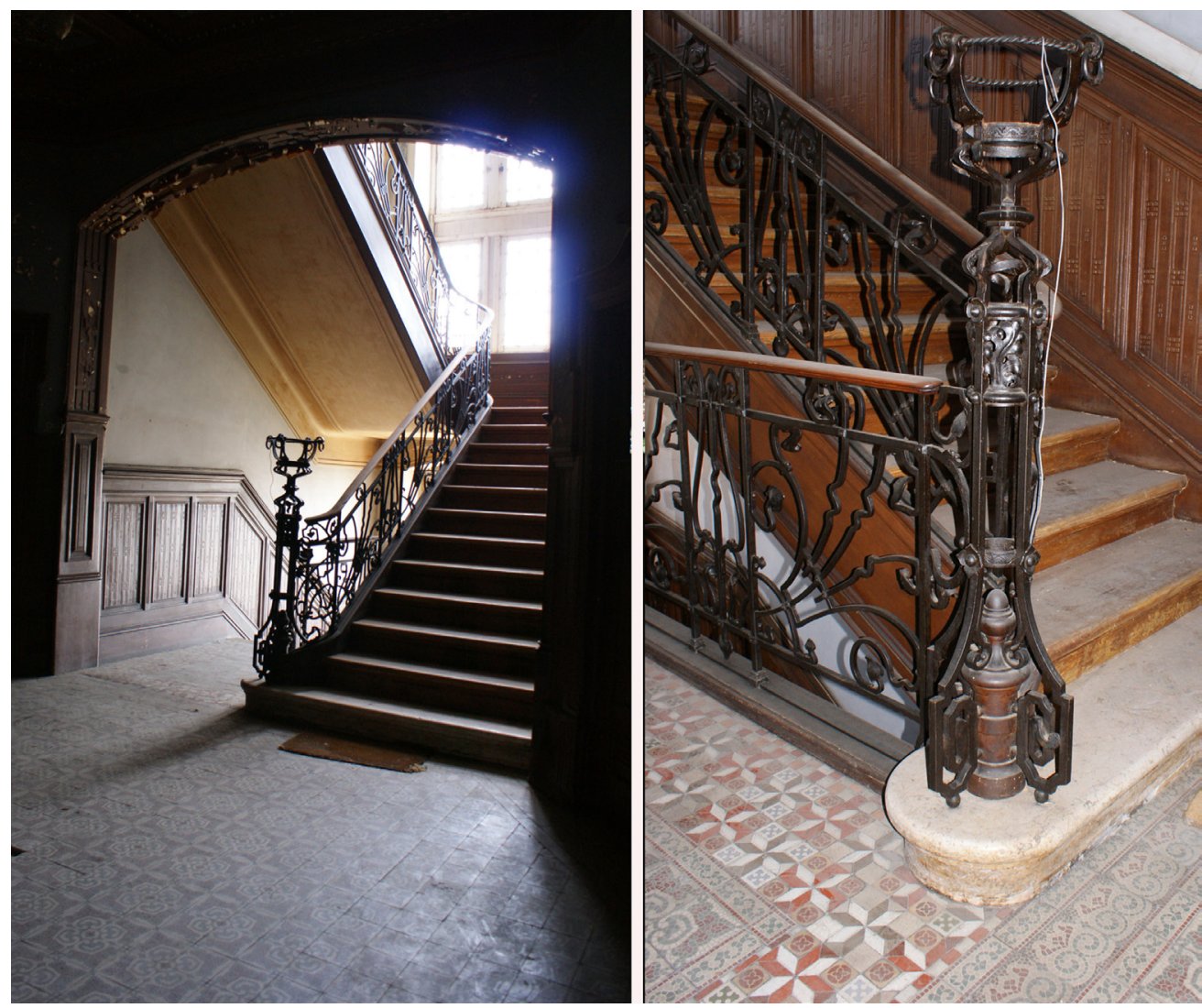

Figura 4 - Vista do hall e pormenor da serralharia Arte Nova da escadaria principal. Fotografias de Mónica Romãozinho.

a divisão do monta-pratos), tipo B (porta de dois batentes para o corredor e armário) e tipo D (quatro portas de dois batentes correspondentes aos vãos mais largos). Com excepção do modelo C (porta de um só batente para o salão e escada de serviço) que aparece representado no desenho da decoração do hall, seriam sempre desenhados cortes horizontais e verticais à escala natural de cada um dos vãos, com as respectivas orientações assinaladas (lado do hall ou lado das salas) onde surgem legendadas componentes fundamentais como o pinázio, com a indicação pregado depois da aplicação do vidro, ou o vidro biselado.

A escada destaca-se pelo trabalho elaborado da serralharia Arte Nova, visível quer no corrimão quer no suporte para vasos que demarca o seu arranque. Os caules orgânicos inscrevem-se numa malha ortogonal demarcada por suportes verticais, afastando-se do movimento mais livre associado a este trabalho no caso dos interiores franceses ou belgas. $\bigcirc$ janelão, com três batentes e encimado por bandeira em arco de volta perfeita, é uma solução recorrente nas habitações projectadas por Korrodi.

hall corresponde à única dependência detalhada (Figura 6), o que enfatiza a sua importância como espaço cénico que deveria impressionar pelo seu 
19. Ver Juliet Kinchin (2008, p.169).

20. “(..) un coffre à bois sculpté ou recouvert de tapisserie, quelques chaises, des patères, un porte-manteau pour accrocher les vêtements, un porte-parapluie, une table avec tout ce qu'il faut pour écrire, une glace pour que les dames puissent réparer le désordre de leur toilette, voilà tout l'ameublement que comporte l'antichambre." ; cf. RisPaquot (1894, p.194).

21. À semelhança da baywindow que consistia numa reentrância de planta poligonal, também muito frequente nas salas ou quartos de tipologias habitacionais inglesas.

22. Azulejaria Arte Nova na varanda de Casa em Blankenberge, Bélgica. Disponível em: http:// matinlumineux.blogspot. com/2011/08/art-nouveau. html. Acesso em: 11 ago. 2011. carácter mais pesado, massivo e simples, sendo encarado como um espelho da dignidade familiar apregoada pelo dono da casa ${ }^{19}$. A preocupação relativa à unidade espacial é inclusivamente evidente quando constatamos que a própria geometria octogonal do espaço se estende ao desenho dos caixilhos dos vidros das portas que, por sua vez, seguem o alinhamento do lambril. Na planta desta divisão, Korrodi não desenhou nenhuma peça de mobiliário específica, mas os tratados da época aconselhavam "uma arca em madeira esculpida ou coberta de tapeçaria, algumas cadeiras, cabides, um bengaleiro para pendurar os casacos, um portaguarda-chuvas, uma consola com tudo o que é necessário para escrever, um espelho para que as senhoras possam reparar a desordem da sua toilette, eis o mobiliário que comporta uma antecâmara"20.

Nos dois cantos chanfrados do hall, emergem os pontos de acesso quer ao escritório quer à sala de almoços, complementada por um zonamento de serviços, constituído pela copa, um pequeno WC e um lava-mãos (canto superior esquerdo da sala). Neste projecto, a copa integra um monta-pratos e um móvel trinchante que se destina a apoiar a recepção das travessas.

Ao contrário de outros projectos, vemos aqui emergir duas salas de refeições, inter-comunicantes e que seguem, na sua disposição, uma lógica de axialidade. Embora a planta aponte para uma relação de total fluidez entre elas, na fase construtiva foi inserida uma porta envidraçada, que Korrodi designa de "guarda-vento".

A sala de jantar é iluminada quer por uma janela de sacada que conduz a uma pequena varanda de ângulo quer por uma bow-window de planta semicircular, solução espacial importada da Inglaterra ${ }^{21}$, que em planta correspondia à varanda principal e que comunicaria com o interior através de duas portas simétricas de dupla folha, entre as quais estava prevista uma mesa de apoio (Figura 7). É interessante confirmar através da planta do "pavimento nobre" que as colunas dessa varanda foram já executadas em betão. A bow-window acabaria por funcionar como extensão da sala de jantares mas os zonamentos continuariam a ser diferenciados através do próprio tratamento do pavimento: soalho de madeira no caso da zona de refeições, mosaico com padrão geometrizado (castanho, marfim, sangue-de-boil no caso da bow-window. Relativamente à varanda, é de evidenciar o valor plástico dos seus painéis de azulejaria Arte Nova, cuja temática naturalista e paleta cromática os aproxima de uma casa situada em Blankenberge na Bélgica ${ }^{22}$. O lambril que percorre toda a sala, surge demarcado por elementos verticais e revestido a papel castanho oleado que imita o couro, fabricado em Inglaterra pela Lincrusta, também ele marcado por divisões verticais, ao longo das quais de dispõe sempre o mesmo motivo floral geometrizado colocado a alturas diferentes, atribuindo ritmo a este mesmo plano.

Regras de higiene mais pesadas aplicavam-se então mais à sala de jantar do que a qualquer outro espaço de recepção e enfatizava-se a importância de revestimentos laváveis, a exemplo do que ocorria na França: "a sala de jantar deve ter de preferência paredes pintadas a óleo, podendo ter também as suas 
paredes revestidas com tapeçaria de cor neutra, panneaux decorativos representando assuntos simples: paisagens ou naturezas mortas" 23 . $\bigcirc$ embasamento apresenta maior profundidade com as suas almofadas e a cimalha, mais alta do que era comum, integra quer um friso marcado por linhas horizontais quer uma faixa composta de elementos florais, trabalhados em stencil e com a paleta pastel característica do movimento Arte Nova lazul, salmão, vermelho em pequenas quantidades).

A parede, pintada de castanho, integra frisos com trevos pintados a castanho e creme (em stencil novamente), de grande abstracção. Mísulas de recorte quadrado, pontuadas no meio por uma roseta e inferiormente por uma sequência de esferas, prolongam-se sob a forma de frisos nervurados em direcção ao tecto, atribuem-lhe ritmo e quando se intersectam dão origem a pequenos quadrados que
23. "(...) la salle a manger doit avoir, de préférence, des murs peints à l'huile, elle peut aussi avoir ses murs tendus d'une tapisserie de teinte neutre, ou mieux de panneaux décoratifs représentant de très simples sujets : paysages ou natures mortes"; cf. Monique Eleb e Anne Debarre (1995, p.110).

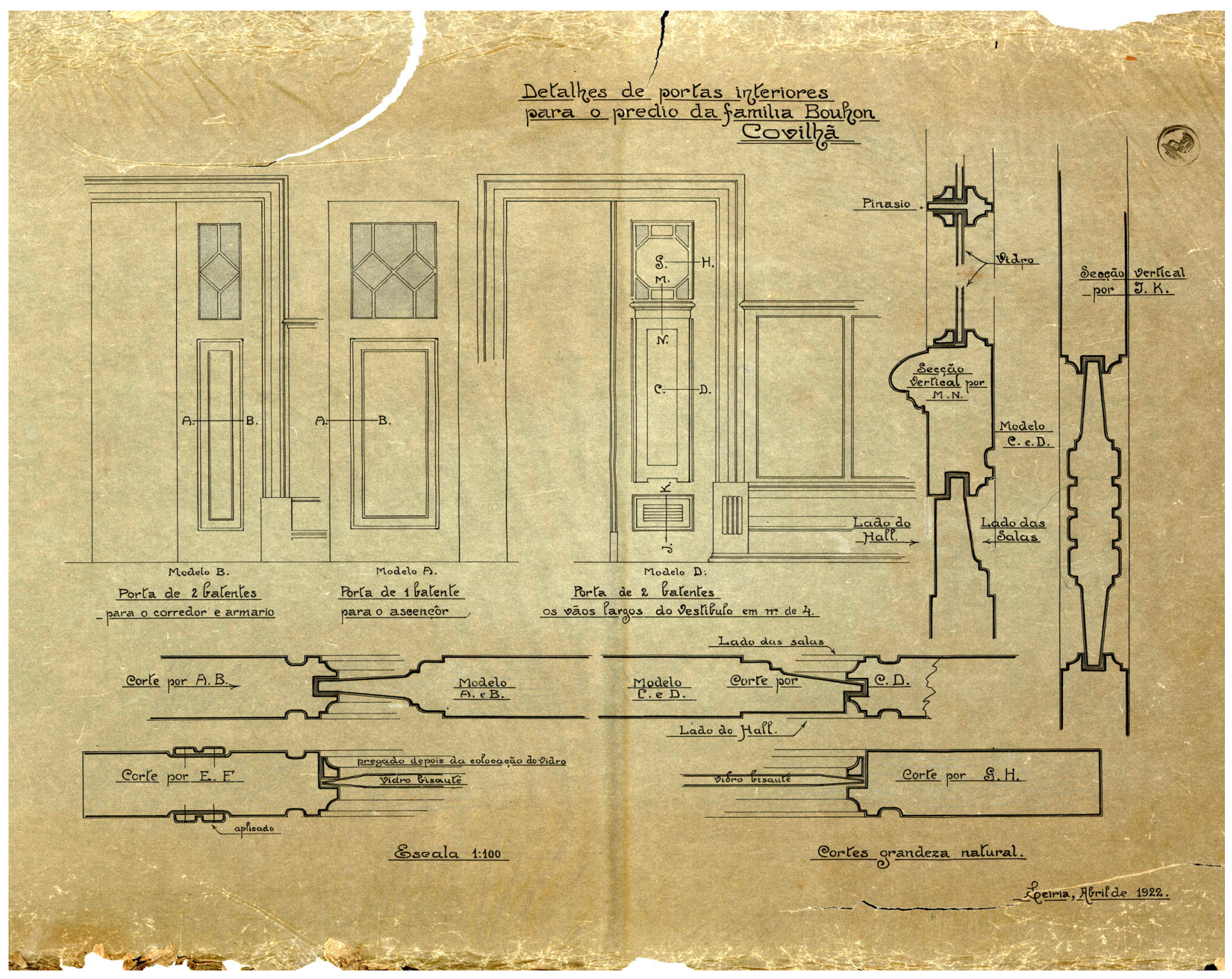

Figura 5 - Detalhes de portas interiores da casa da família Bouhon, Covilhã (mapa de vãos). Esc. 1 : 10 e escala natural. Abril de 1922. Acervo do Arquivo Distrital de Leiria. 


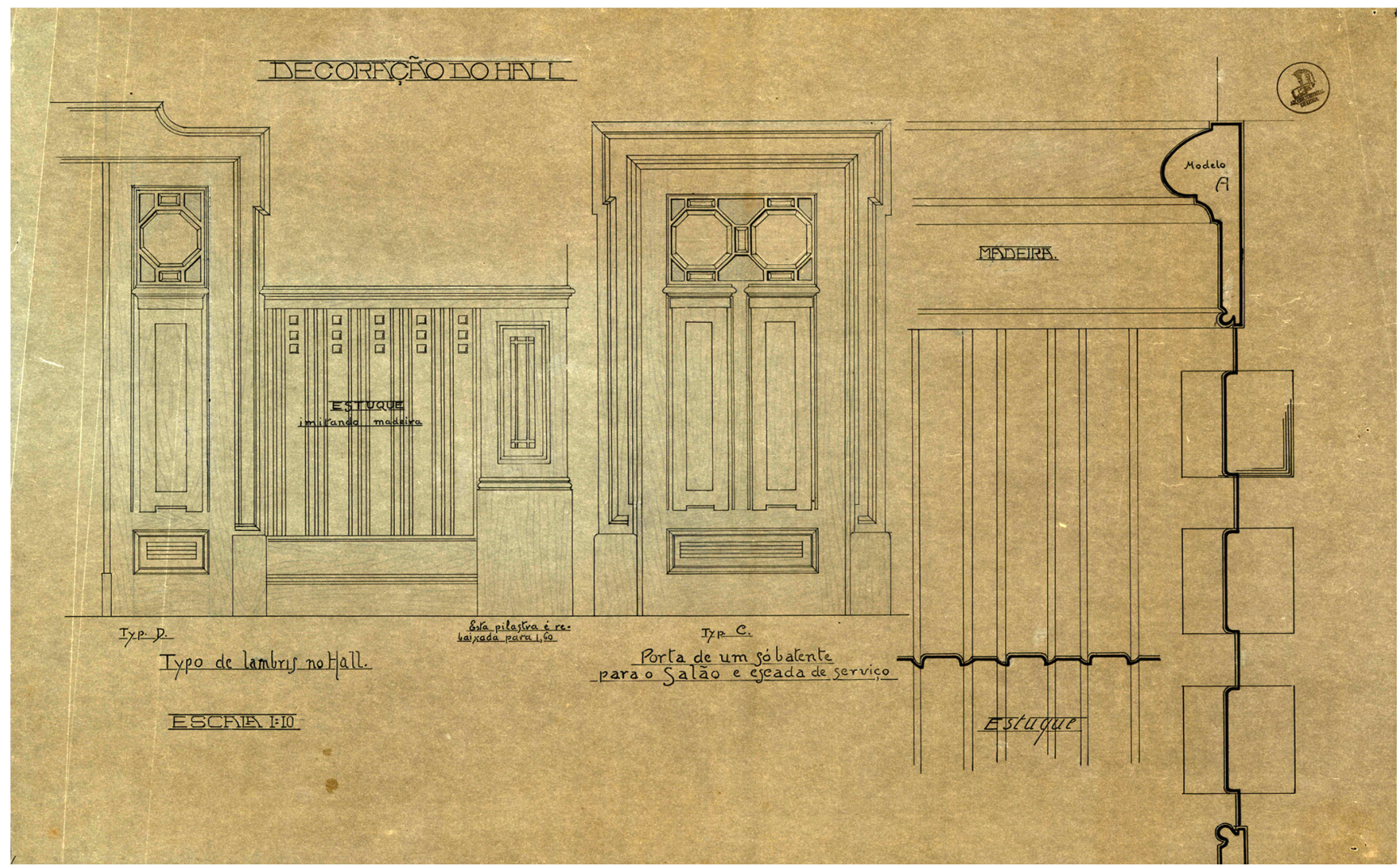

Figura 6 - Decoração do hall (vistas de porta de duplo batente e lambril, porta simples e corte construtivo). Esc. 1: 10. Acervo do Arquivo Distrital de Leiria.

Figura 7 - Bow-window da sala de jantar. Fotografia de Mónica Romãozinho.

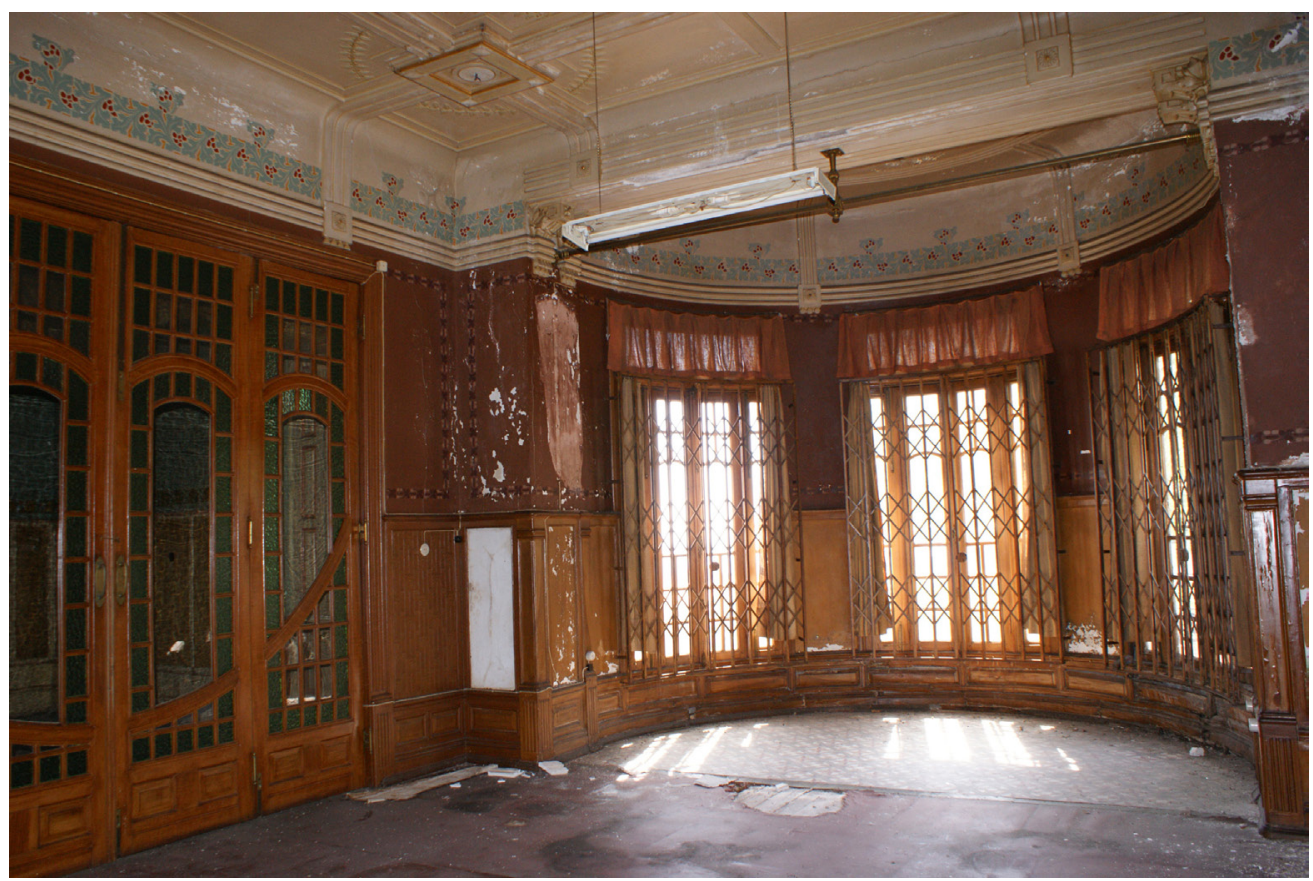


acolhem os quatro pontos de iluminação e que se inscrevem em formas circulares demarcadas a estuque. Estes mesmos frisos, marcados por sucessivas linhas horizontais, definem a cimalha. $\bigcirc$ dourado faz a sua aparição quer nas mísulas quer nos quadrados do tecto, pormenores que se evidenciam deste modo face à cor dominante que é o marfim. As proporções da sala também favorecem a integração da mesa de refeições e respectivas cadeiras e, deste modo, os espaços residuais seriam minimizados. Por outro lado, críticos da época aconselhavam também a que a sala de jantar se desenvolvesse em profundidade a fim de evitar criar sombra sobre si mesma ${ }^{24}$.

mobiliário consistia nas seguintes peças: um móvel trinchante, um bufete integrado na parede contígua à varanda da frontaria, outro bufete de desenho similar, dois argentiers ${ }^{25}$ de dimensão idêntica que ocupam a parede lateral esquerda, uma mesa centralizada com seis lugares previstos e mais uma mesa ou aparador de apoio.

A Arte Nova revela-se ainda nos cachorros que sustentam a grande viga. Estes suportes revelam uma composição escultórica de troncos e caules secos entrelaçados, parecendo os mesmos caules assumir a forma de ossos na parte frontal numa linguagem que os aproxima de certos pormenores manuelinos (Figura 8). Uma porta envidraçada, atravessada em toda a sua extensão por um arco abatido invertido e que apresenta quatro batentes com pequenos vidros quadrados verdes e superfícies espelhadas, separa a sala de jantares da sala de almoços, seguindo tendência internacional: "A moda francesa do emprego generalizado de grandes superfícies envidraçadas chegou com a Art Nouveau ou Modern Style"26. Cada batente da porta é pontuado superiormente por um arco de volta perfeita e os puxadores em bronze apresentam um contorno orgânico e fechado sediado na Arte Nova (Figura 8). A relação de maior fluidez entre espaços foi bastante propiciada pela Arte Nova assim como o recurso ao vidro colorido ou ao vitral. Neste caso, o vidro colorido verde apresentava um acabamento martelado que se relacionava de modo harmonioso com a paleta cromática escolhida em ambas as salas de refeições.

À semelhança do que Korrodi fizera em outras casas, são trabalhadas alternâncias cromáticas de divisão para divisão e essa diferenciação revela-se desde logo nos vãos de acesso. Neste caso, a mesma porta apresenta os batentes em madeira com cores diferentes de um lado e do outro: envernizadas no lado que confina com a sala de jantares, e pintadas de marfim e rosa no lado que confina com a sala de almoços. A madeira envernizada dá lugar à madeira pintada de marfim com pormenores pintados a rosa velho, nomeadamente frisos ao nível dos aros das portas e de contorno às próprias almofadas dos batentes e dos envidraçados (em vidro biseauté) e ainda nos limites superiores do rodapé e do lambril. Os envidraçados assumem aqui uma maior verticalidade e os cantos dos seus losangos alinham com o friso superior do lambril, também este em rosa velho e marfim.

Na sala de almoços, o papel que reveste o lambril é o mesmo da sala de jantares, mas agora pintado de casca de ovo, o que parece evidenciar mais os seus motivos que consistem em folhas com caules rectilíneos e interligados assim
24. É o caso de Julian Guadet, que criticava a iluminação zenital; ver Monique Eleb e Anne Debarre (1995, p.108).

25. Argentários que se destinam à exposição das pratas.

26. "La mode française de l'emploi généralisé des grandes surfaces de verre est venu avec l'Art nouveau, ou 'Modern Style', comme ils l'appellent" ; cf. Peter Thornon (1986, p.315). 
como pequenos quadrados subdivididos, todos inscritos nas listas verticais da composição (Figura 9). Também o castanho das paredes dá lugar a um azul pontuado logo acima do limite do lambril, por frisos em papel com rosas /cor de mel) e folhas de pétalas azuis e verdes sobre vermelho, e acima da verga da porta por apontamentos mais pequenos (lírios azuis e folhas em dois tons de verde). Esta prática de substituir motivos escultóricos em estuque por aplicações de papel era comum na Inglaterra e Escócia no séc. XIX como podemos ver na figura anexada. $\bigcirc$ pavimento da sala de jantares é em soalho corrido de pinho e o da sala de almoços é mais delicado, em solho à inglesa, com uma cercadura em parquet e mosaico de madeira, num jogo enriquecedor de molduras e de tonalidades. $\mathrm{Na}$ sala de almoços, implantou um bufete e outro móvel trinchante.
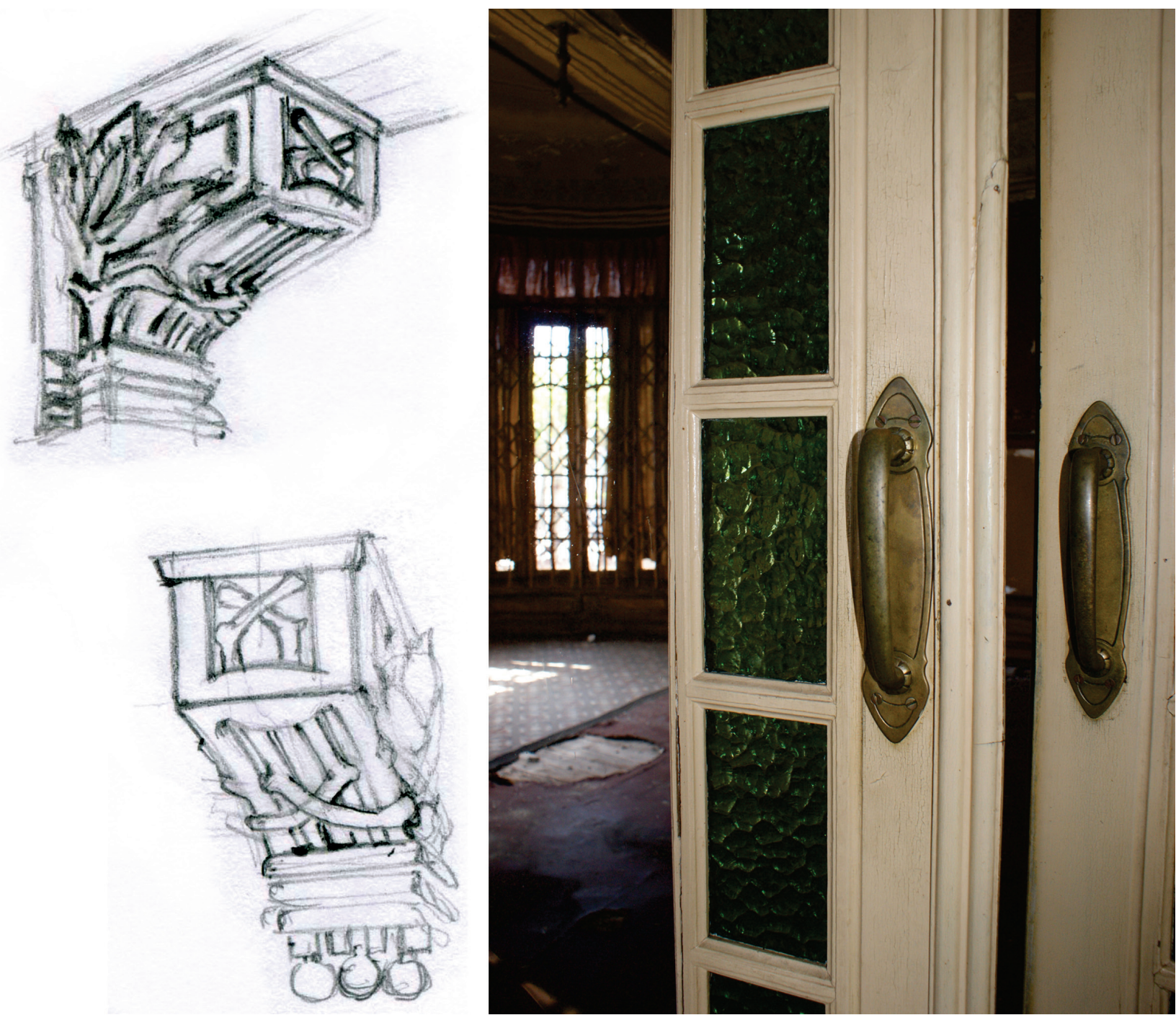

Figura 8 - Pormenores: cachorros que sustentam o vigamento da sala de jantar e manípulo da porta que separa as salas de refeições. Desenho e fotografia de Mónica Romãozinho. 
Há que apontar um pormenor funcional, um pedal localizado no pavimento que acciona a campainha, permitindo chamar as criadas à hora das refeições segundo padrões em voga na França: "Nos apartamentos burgueses, uma campainha localizada na sala de jantar permite chamar a criada encarregue do serviço de refeições. O contacto pode ser feito por um interruptor, ou de modo mais
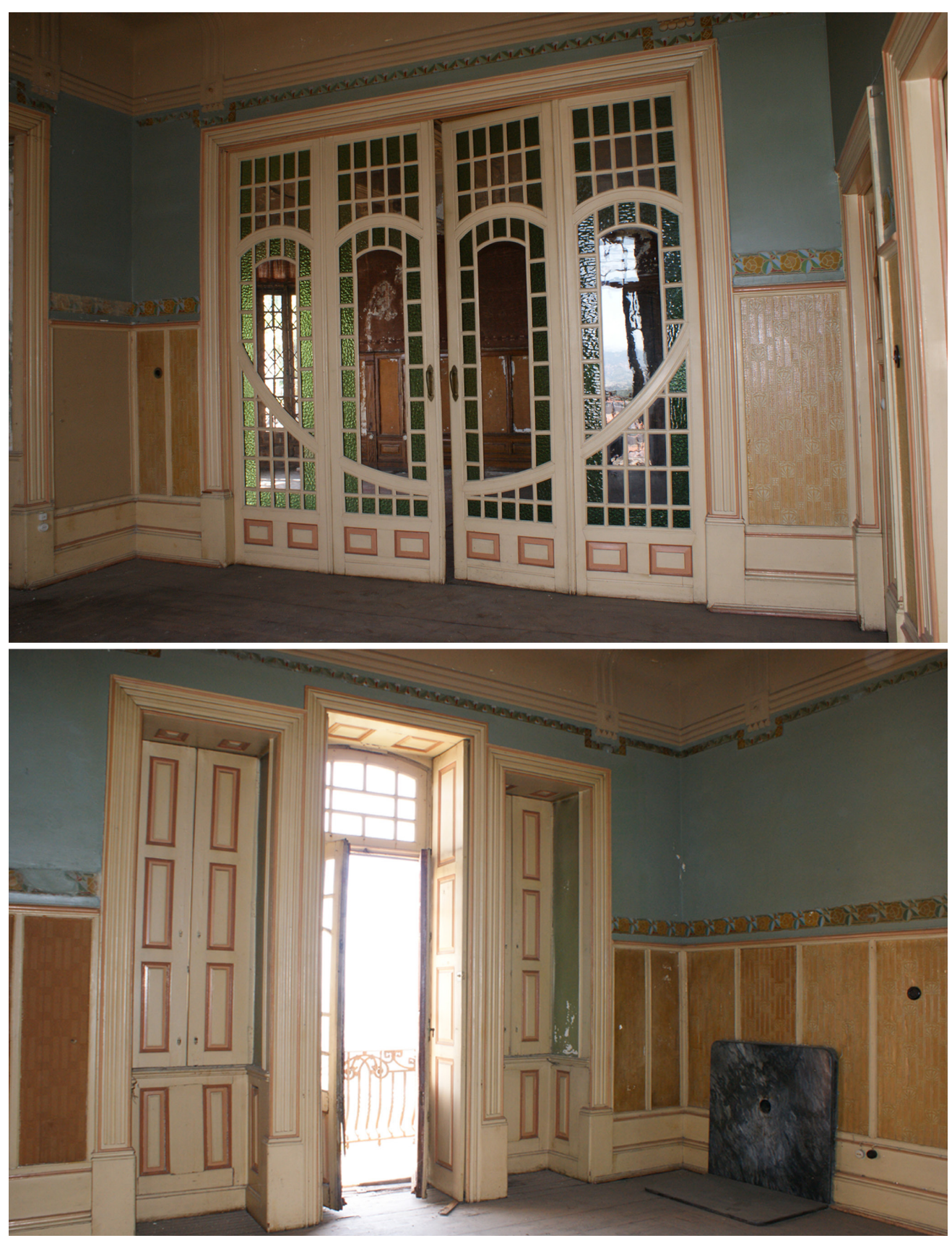

Figura 9 - Sala de almoços: porta de ligação à sala de jantar (em cima) e vão tripartido com varanda (em baixo). Fotografias de Mónica Romãozinho. 
27. "Dans les appartements bourgeois, une sonnette placée dans la salle à manger permet d'appeler le domestique chargé du service du repas. Le contact peut être donné par une poire ou, de façon plus discrète, par une pédale de parquet. Ces inventions, permises par le progrès techniques, répondent à une demande des habitants, celle de l'efficacité du service de domestiques 'invisibles' "; cf. Monique Eleb e Anne Debarre (1995, p.402).

28. "By long tradition the English dining-room is serious and dignified in character, its colour-scheme rather dark than light, its furniture heavy and made of polish mahogany; it has a Turkish carpet on the floor and oil-paintings, preferably family portraits, in heavy gilt frames, on the walls. But in recent times a more joyful atmosphere has entered this room also. Here too the decoration is becoming ever lighter; furniture modeled on that of Chippendale and Sheraton period has become light and pleasing; the heavy curtains in dark material have given way to curtains of a lighter and brighter material."; cf. Hermann Muthesius (2007 [1904], p.206).

29. Desenho original da fábrica alemã Grohn (c.1905), ainda hoje sediada em Bremen. Existia então uma forte cooperação entre as suas fábricas e muitos padrões da Helman Céramique correspondem a desenhos da fábrica Grohn. Disponível em: http://cgi. ebay.com.sg/ ORIGINALANTIQUE-Art-NouveauMajolica-tile-150-PCS$/ 220684921022$ ? $p t=$ A r c hit e c t u r a $1_{\text {_ }}$ $\mathrm{G}$ a $\mathrm{rd}$ e $\mathrm{n} \& \mathrm{~h}$ a $\mathrm{s} \mathrm{h}=$ item3361d8a8be. Acesso em: 11 ago. 2011. discreto, por um pedal de parquet. Estas invenções permitidas pelos progressos técnicos, respondem a uma exigência dos habitantes, a da eficácia do serviço do pessoal doméstico 'invisível' "27.

Embora o tecto da sala de almoços apresente um desenho similar ao anterior, surge aqui complementado por faixas pintadas, com motivos e cores que estabelecem uma relação de continuidade temática em relação aos frisos florais das paredes (roseiras com rosas na sua cor natural e também amarelas, complementadas pelos seus caules espinhosos e folhas). Mais uma vez, verificamos que os próprios frisos lineares partem do alinhamento das ombreiras das portas ou da respectiva mediatriz.

Em ambas as salas, surgem desenhados em planta dois rectângulos a tracejado que corresponderiam a duas mesas, o que significa que Korrodi terá pensado num conjunto de salas suficientemente versátil ao ponto destas funcionarem como uma só sempre que a família Bouhon reunisse um maior número de convidados. O lava-mãos de apoio não chegaria a ser inserido, dando lugar a uns arrumos. Existe, indiscutivelmente, um contraste entre estas duas dependências, diferença que se faz sentir no acabamento dos materiais e uso da cor e padrões e que podemos associar à alternância entre domínio masculino e feminino que se fazia sentir de modo particular no design de interiores. A influência exercida pelos modelos ingleses evidencia-se novamente no modo como tradição e novas soluções surgem articuladas, salvaguardando sempre os valores específicos que se pretendia comunicar no âmbito da concepção de um espaço de recepção:

Na sequência de uma longa tradição, a sala de jantar inglesa é séria e digna no seu carácter, a sua composição de cores é mais escura do que leve, a sua mobília é pesada e feita de nogueira polida, apresenta um tapete turco no pavimento e pinturas a óleo, preferencialmente retratos familiares, em pesadas molduras douradas nas paredes. Nos tempos mais recentes, uma atmosfera mais alegre invadiu também esta dependência. Também aqui a decoração se está a tornar mais leve; o mobiliário baseado no período de Chippendale e Sheraton tornou-se mais mais leve e aprazivel; as pesadas cortinas em material escuro deram lugar a cortinas de material mais leve e luminoso ${ }^{28}$ (Figura 10).

Três portas laterais dão acesso a um pequeno corredor, copa com monta-pratos e arrumos de apoio. OWC social revela uma escolha cuidadosa de acabamentos. O branco é a cor dominante, pontuado apenas por detalhes a dourado associados à faiança monocromática com decoração moldada e vidrada, importada da Bélgica e fabricada pela Helman Céramique Sint Agatha-Berchem Belgium ${ }^{29}$. A parede divide-se em três níveis: um rodapé de azulejo com festões, uma faixa de azulejo com folhas enroladas, o corpo central revestido a ladrilho vidrado (solução utilizada na Bélgica de que são exemplo os projectos de Victor Horta), um friso de azulejos de padrão idêntico ao seguido no WC que se the sobrepõe no piso dos quartos (conjunto simétrico de folhas e rosas estilizadas, circunscritas em círculo, que lembram os padrões de Mackintosh), encimado pela última faixa composta por contas, rosetas 

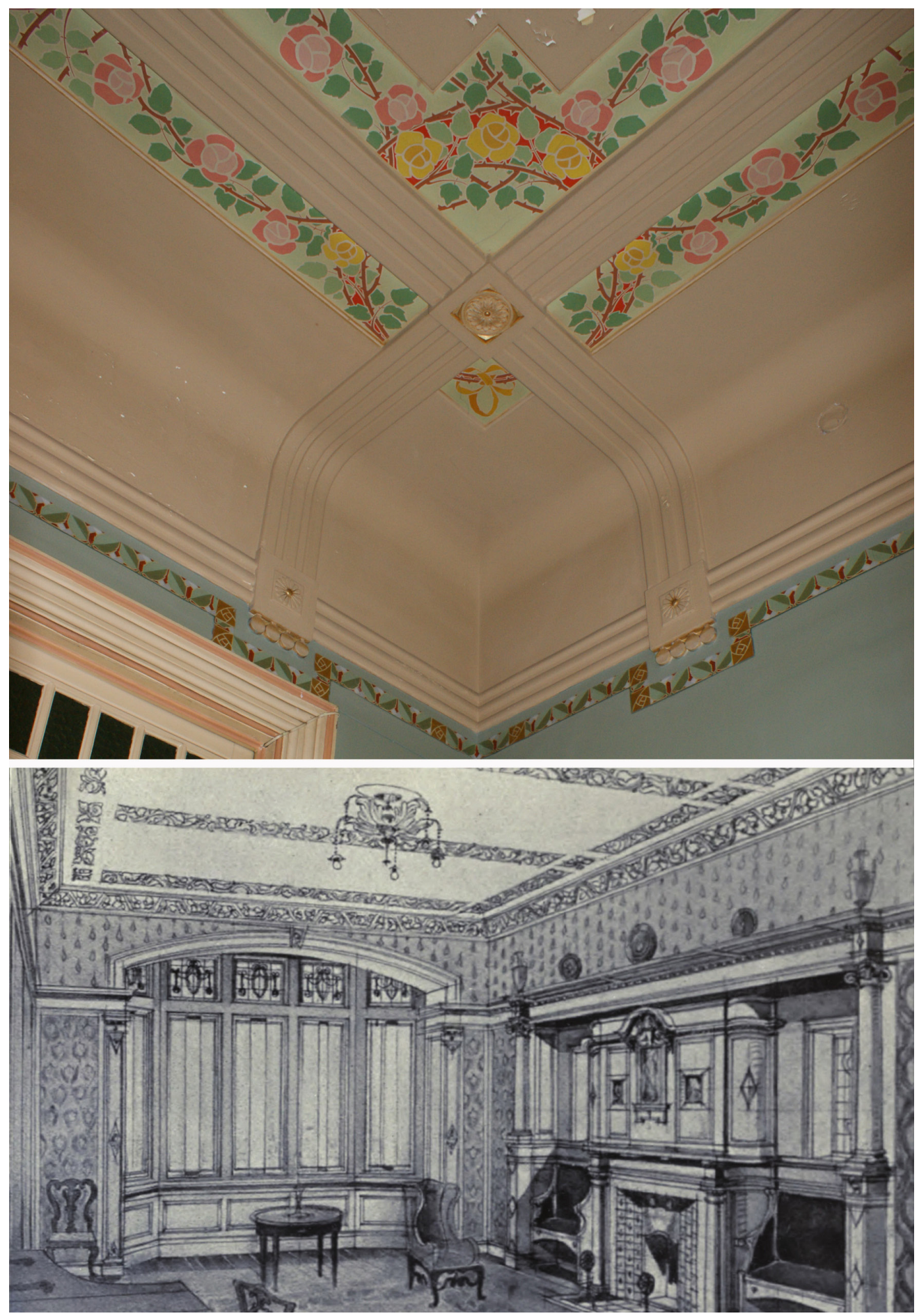

Figura 10 - Soluções decorativas empregues no tecto e paredes da sala de almoços. Fotografia de Mónica Romãozinho. Exemplo similar de aplicação de frisos em papel na cimalha e tecto. Drawingroom de casa situada em Haffield Drive, Kelvinside, Glasgow. Fonte: Academy Architecture and Annual Architectural Review, London, v.29, p.93, jan.jul. 1909. 
30. Numa planta datada de 1919, não constava nenhuma divisória envidraçada. O vão aparece desenhado em plantas posteriores, mas era menor e consistia numa porta ladeada de duas janelas simétricas, surgindo posteriormente alterado no mapa de vãos final.

31. Informação que figura no desenho de pormenorização do guardavento da sala e do salão que integra o mapa de vãos do projecto. também integradas em círculos e por um novo alinhamento de folhas enroladas (Figura 11).

O pavimento apresenta um plano central de mosaicos coloridos similares aos das varandas (em castanho, marfim, azul, sangue de boi e ocre) que formam desenhos geométricos como uma roza-cruz ou um trevo de quatro folhas. A moldura deste plano apresenta geometrismos a duas cores e o plano rectangular junto à janela dá continuidade à mesma paleta (castanho escuro e marfim).

A saleta e a sala ou salão, como aparece designado no desenho de pormenorização, comunicam entre si através de um guarda-vento, de duplo batente, idêntica à que separa as salas de refeições. $\bigcirc$ arco de circunferência que determina um das travessas curvas, apresenta o seu centro no alinhamento dos dois arcos superiores e termina no ponto de partida da linha do lambril. Esta relação métrica dos caixilhos e lambris manifesta-se em todas as dependências e também ao nível das janelas de sacada cujas curvaturas não são aleatórias ${ }^{30}$.

As suas paredes apresentam um lambril em tela relevada e pintada de casca de ovo da marca Lincrusta $^{31}$, igualmente ritmado por linhas verticais em relevo, mas agora fragmentadas e alternadas com sequências de pequenos pontos que também encimam o motivo integrado em cada uma dessas faixas fragmentadas, constituído por uma folha. No canto superior direito do desenho
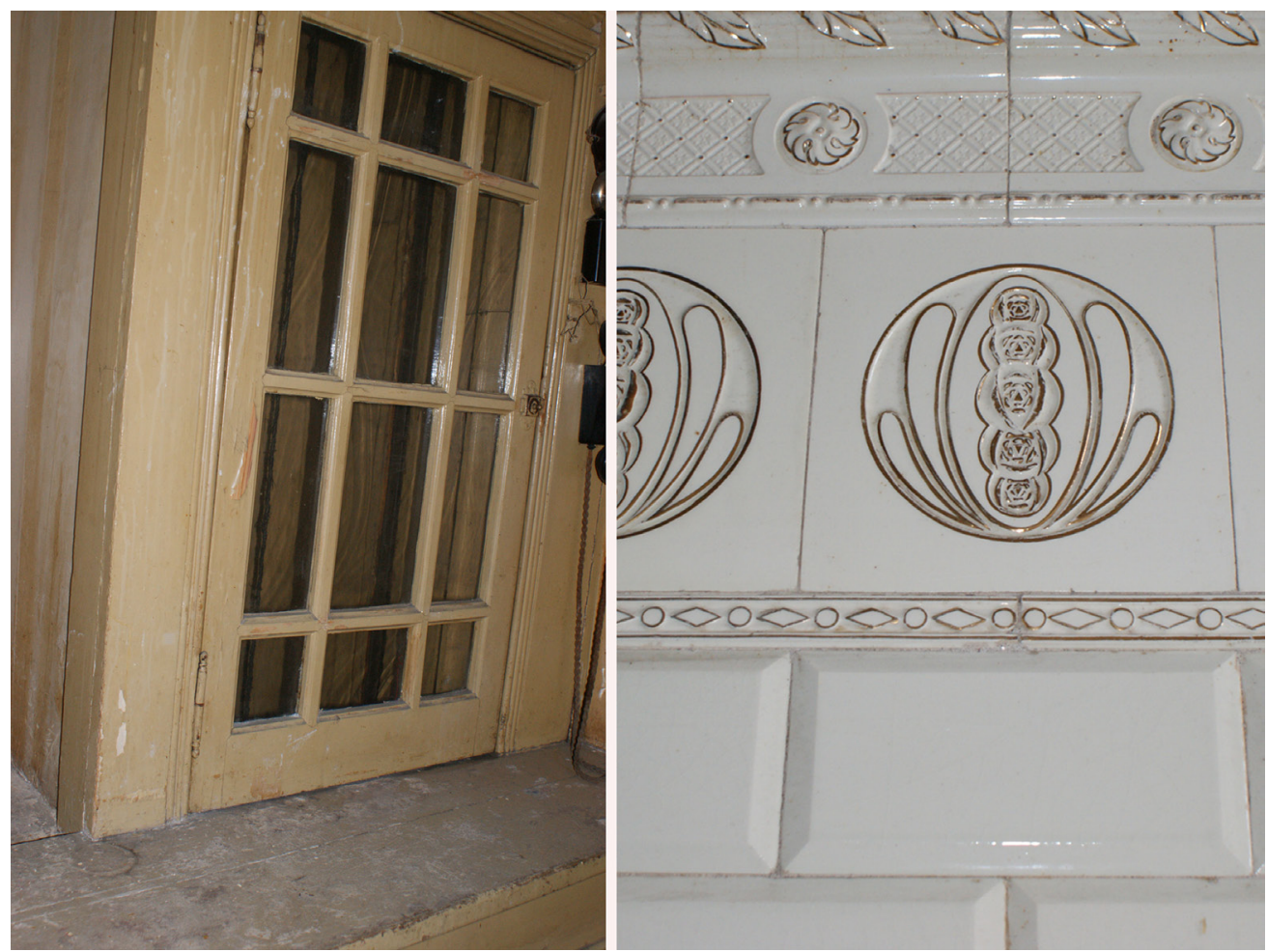

Figura 11 : Pormenores: monta-pratos localizado na copa e azulejaria / ladrilho vidrado do WC social. Fotografias de Mónica Romãozinho. 
em vista da porta envidraçada e de parte do lambril, observa-se a pormenorização do arranque deste último. Aparece representado em vista ampliada e também seccionado horizontalmente, vendo-se a cantoneira assim como uma baguette que seria aplicada após a aplicação do revestimento (Figura 12).

Segundo informações cedidas pela fábrica em causa, o papel com relevo, da marca Lincrusta, teria sido primeiramente aplicado através de uma cola (goma arábica $n .^{\circ} 1$ ou dextrina) e posteriormente oleado e envernizado segundo o seguinte processo: lubrificação da superfície, aplicação de primário à base de óleo, aplicação de uma ou duas camadas de pigmento misturado com óleo (neste caso uma base de casca de ovo misturada com linhaça ou terebentina), uma demão muito fina de verniz opaco (scumble glaze) enquanto a tinta ainda está molhada e, no final, uma camada de verniz tradicional a fim de proteger a base oleada ${ }^{32}$. $O$ papel de parede que cobre a restante parede até à sanca apresenta
32. Informação cedida por Andy Sarson (Lincrusta Technical Manager).

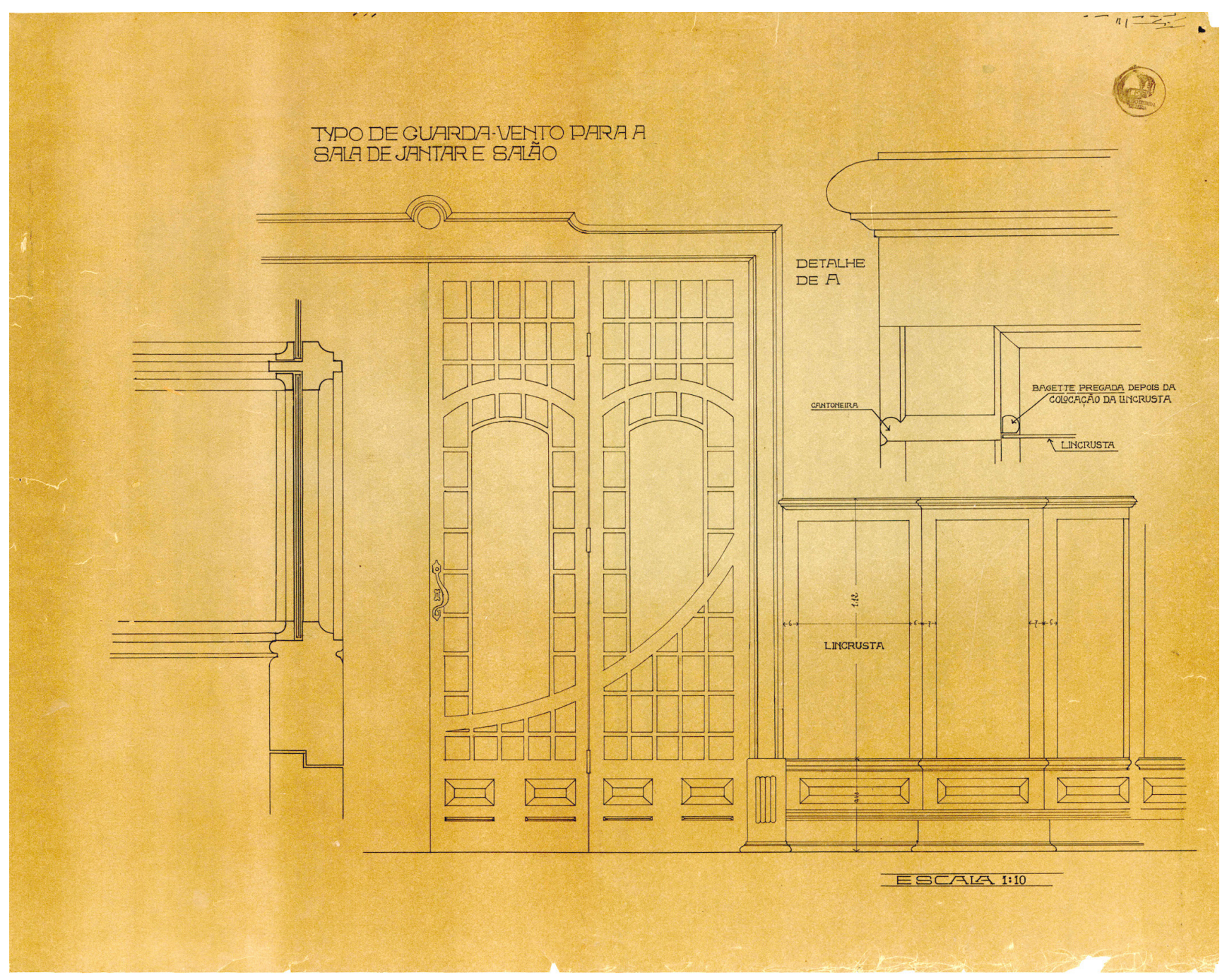

Figura 12 - Pormenorização do guarda-vento da sala de jantar e salão. Esc. 1 : 10. Acervo do Arquivo Distrital de Leiria. 
33. O Aesthetic movement, dedicado à Beleza no seu estado mais puro, eclodiria nos anos 1860 , correspondendo a uma corrente de transição para o movimento Arts and Crafts, amplamente influenciada pelo Oriente. Entre os seus seguidores encontravam-se Dante Gabriel Rossetti (18281882) e William Morris: "The aesthetic movement stood in stark and sometimes shocking contrast to the crass materialism of Britain in the 19th century. 'Art for art's sake' was its battle cry, a slogan that originated with the French poet Théophile Gautier."; cf. Fiona Maccarthy (2011). motivos florais dourados simetricamente dispostos sobre fundo azul, cuja linguagem faz lembrar alguns papéis de William Morris (1 834-1896), em particular o padrão St. James. A saleta (Figuras 13 e 14) evidencia-se ainda pela sua planta de tectos e pela originalidade dos seus estuques, referenciados numa tradição clássica mas contrariados por aplicações de papel de parede e interpretações orgânicas de flora.

Mais uma vez, Korrodi opta por duas fontes de luz simetricamente posicionadas ao invés de uma em posição centralizada lo que já acontecera na sala de almoços). Esses pontos de iluminação demarcam o centro de semicircunferências divididas em oito partes, parecendo evocar a visão de pérgolas vistas de baixo, ao longo das quais se entrelaçam rosas com corolas pontuadas a dourado e os seus caules e folhas dispostos num movimento orgânico. Duas molduras enquadram toda a composição: a mais interior formada por nervuras e quadrados com motivos nos pontos de intersecção (como na sala de almoços), a exterior por um friso com rosas silvestres brancas, caules e folhas. $\bigcirc$ tecto da sala ou salão revela o mesmo tipo de enquadramento e linguagem: quartos de circunferências com rosas, caules e espinhos que rematam os cantos dos tectos, frisos com rosas silvestres vermelhas, caules e folhas. Embora este tipo de frisos apareça com o movimento Arts and Crafts, estes são valorizados e integrados em interiores Estéticos ${ }^{33}$ ou Arte Nova.

A sala (Figuras 15 a 17) encontra-se estruturada em duas zonas: a de maior área, que integra uma lareira e que se destinava à família, assim como um recanto ao fundo, separado da área anterior por uma arcada, constituída por um arco central abatido e por dois laterais com balaustrada, onde as crianças da família Carneiro tocavam pianola. Esta última zona assumia uma vocação de espaço de encenação e apresentava um banco fixo de apoio, em continuidade com a linha do lambrim da sala. De acordo com a planta, esta pequena área receberia inicialmente um sofá fixo e perfeitamente ancorado na métrica da arcada, mas esta solução seria abandonada. $\bigcirc$ tecto segue a linha formal dos dois tectos anteriores, mas aqui as semi-circunferências dão lugar a uma composição mais rectilínea, mas igualmente decorada por roseiras, em que os seus caules e folhas transgridem pontualmente as molduras geometrizadas que regulam a composição. Se observarmos atentamente a planta de tectos do conjunto de recepção formado pelas várias salas, é-nos possível arriscar em associá-los à Arte Nova, não só pela criatividade das suas composições inspiradas na natureza que oscilam entre um registo mais orgânico ou mais linear, mas também pelo afastamento em relação a outros estilos que eram então reinterpretados ou simplesmente copiados.

Em ambas as salas, observamos pavimentos de mosaicos de madeira, que formam uma composição alternada de formas quadrangulares e quadradas. $\bigcirc$ tapete central formado por este jogo é envolvido por uma cercadura em parquet espinhado. A restante integração do mobiliário no salão segue também algumas "modas" ditadas na altura e divulgada pela literatura internacional de especialidade: "Em relação à lareira, coloca-se à sua frente uma mesa de centro, ornada com um 

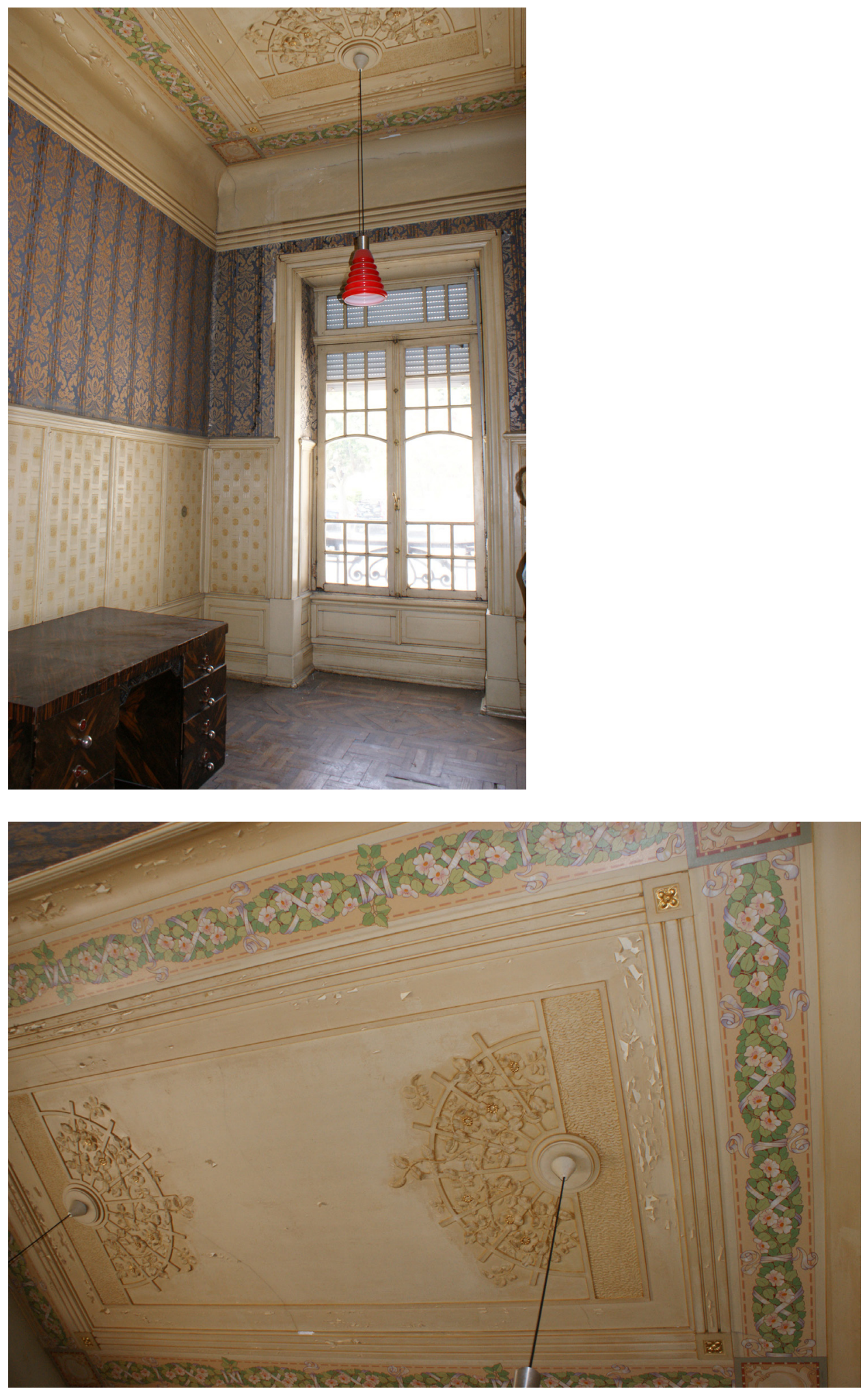

Figuras 13 e 14 - Perspectiva e tecto da saleta. Fotografias de Mónica Romãozinho.

Annals of Museu Paulista. v. 21. n.2. Jul.-Dec. 2013. 
34. "Vis-à-vis la cheminée, lui faisant face, se place la table de milieu, ornée d'une pendule et de deux candélabres ; de chaque côté plusieurs sièges. A droite et à gauche de la cheminée, surmontée d'une glace, un canapé et des fauteuils" ; cf. Ris-Paquot (1894, p.195).

35. "The oak is man, in firmness drest, / With strength of fondness in his breast, / Delighting in the lie:-/the ivy is the gentle wife."; cf. Scots Magazine (Marc.1789), apud, Juliet Kinchin (2008, p.170).

36. "Le blanc commence à se généraliser, souvent avec une tendance vers l'ivoire, mais il ne fut pas seulement utilisé par Voysey, Mackintosh et les progressistes de cette génération, puisque, par exemple, certains meubles du Sandringham de la reine Alexandra étaient peints en blanc en blanc - légèrement rechampis d'or toutefois et que les styles 'Louis Seize' et 'Adam' peints en blanc étaient devenus une réalité indéniable à la fin du siècle" ; cf. Peter Thornon (1986, p.312).

37. Raul Lino e Ernesto Korrodi cruzam-se em 1926 no dia em que ser-lhes-ia atribuído o título de arquitecto, na sequência da saída de um decreto de lei (1925) que determinava que ninguém podia usar a designação de arquitecto sem ter o diploma oficial de uma das Escolas de BelasArtes do país. E será Raul Lino, como presidente da Academia das Belas-Artes que elaborará o discurso póstumo quando Korrodi morre. Raul Lino estudou em Inglaterra e na Alemanha, onde frequentou a Technische Hochschule e trabalhou no atelier do Prof. Albrecht Haupt. Neste sentido compreende-se a proximidade da sua obra aos modelos anglo- relógio e dois candelabros; de cada lado múltiplas cadeiras. À direita e à esquerda da lareira, complementada por um espelho, um canapé e poltronas" ${ }^{\prime 34}$. Os tons dominantes são claros e o branco marfim ou casca de ovo, paleta mais suave e feminina ${ }^{35}$, voltam a invadir os lambris e tectos desta sucessão de espaços sociais destinados à família, aqui como no estrangeiro:

O branco começa-se a generalizar sobretudo uma tendência para o marfim mas ele não foi somente utilizado por Voysey, Mackintosh e progressistas desta geração, pois, por exemplo, certos móveis da rainha Alexandra em Sandrigham, eram pintados em branco - quase sempre ligeiramente pontuados a dourado - e os estilos "Luís XVI" e "Adam" pintados de branco tinham-se tornado uma realidade inegável no final do século ${ }^{36}$.

O conjunto formado pelas salas obedece também a uma orientação solar cuidadosa. Já Raul Lino ${ }^{37}$ expressara essas preocupações na sua obra escrita: "Casas de estar ficam bem quando recebam bastante luz do sol durante a tarde, por isso se orientam de preferência com suas janelas ao Sudoeste ou Oeste" 38 .

O escritório segue o então chamado estilo Renascença, tendência que é visível ao nível do remate superior do lambril, ritmado por pequenos quadrados com volutas ou apainelados quadrados ou rectangulares, pontualmente em ponta de diamante, que se integram na malha de almofadas pré-estabelecida. Quer os cachorros, pontuados por acantos, quer a cimalha que apresenta um trabalho de relevo com sucessivos arabescos executados a estuque, reflectem o mesmo tipo de linguagem. $O$ tratamento atribuído às paredes, neste caso pintadas de verde, é similar ao da sala de jantar, tendo sido pintado um friso através de stencil, cuja temática são os trevos. O próprio interruptor foi integrado no lambril. Dois tons de madeira são alternados quer no lambril quer nas almofadas das folhas da porta.

Dois dos cantos do escritório são chanfrados, recebendo um deles a porta e correspondendo o outro a um nicho em arco de volta perfeita, pintado de azul que acolheria um móvel classeur (arquivador). Entre estes cantos, desenhase na parede uma grande reentrância em arco destinada a um sofá ladeado de duas pequenas mesas. Aqui, o fogão não apresenta uma coifa e apresenta-se absolutamente integrado no desenho do lambril. $O$ tecto, em caixotões de madeira, apresenta as suas superfícies reentrantes pintadas na cor das paredes e contornadas por frisos Arte Nova. $\bigcirc$ caixotão central recebe a base circular de fixação da fonte de luz, elemento que segue a mesma linguagem Renascença, com o seus acantos simetricamente posicionados.

Dada à localização, dimensão e nobreza do tratamento decorativo de superfícies, bem como maior contenção decorativa, subentende-se que este escritório e biblioteca assumiriam também a vocação de espaço de convívio do domínio fundamentalmente masculino, tendência que também era observada na Inglaterra: "Nas grandes casas que possuíam uma biblioteca, tem-se a impressão que esta dependência servia mais como sala de estar do que como local para 


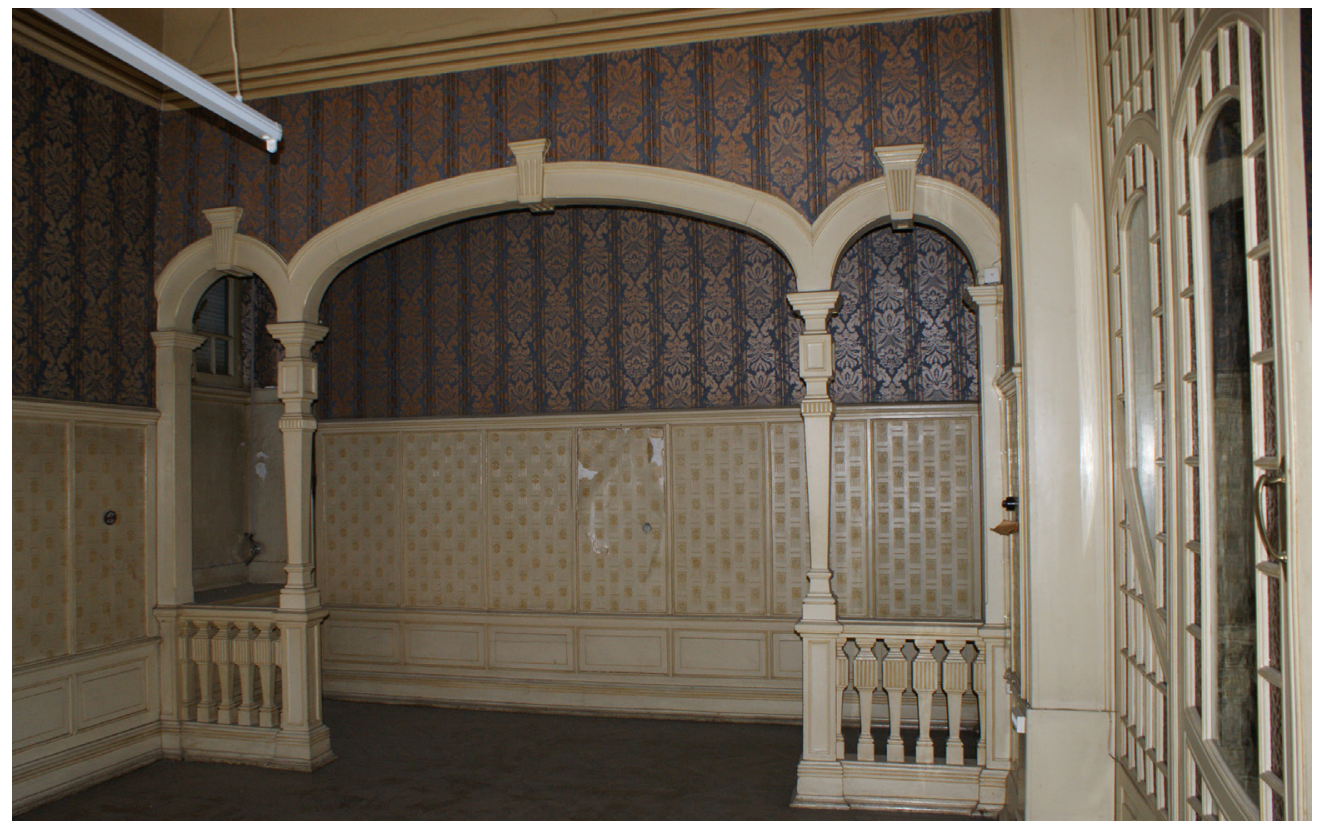

saxónicos apreciados na Alemanha e também determinantes para Korrodi.

38. Cf. Raul Lino (1992 [1941], p.35)

Figura 15 - Pequeno recanto que se forma para lá da arcada tripartida e que podia funcionar como espaço de representação para a família ou convidados. Fotografia de Mónica Romãozinho.
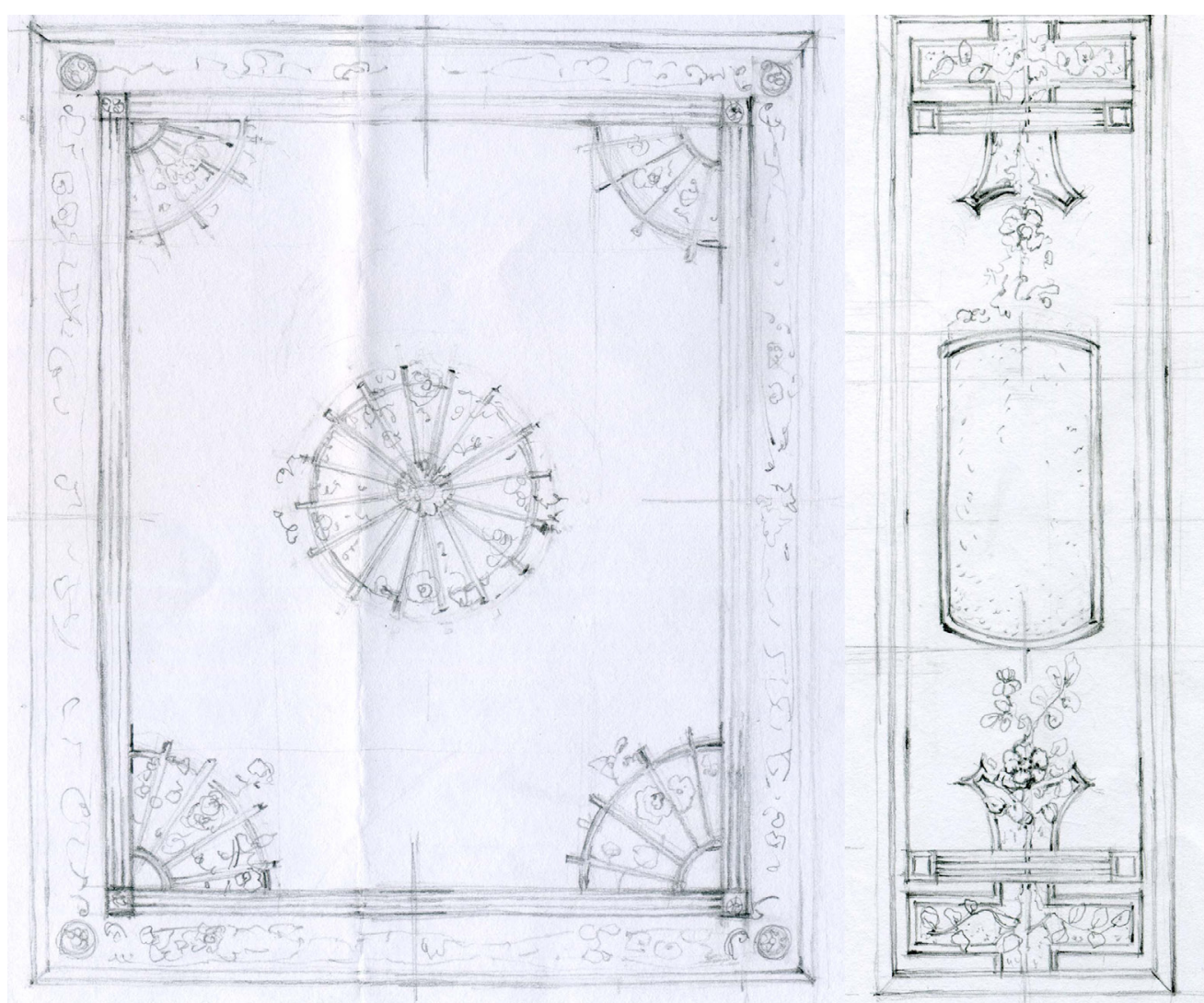

Figura 16 - Plantas de tecto do salão e recanto. Desenhos de Mónica Romãozinho. 
39. "Dans les grandes maisons qui possédaient une bibliothèque, on a l'impression que cette pièce tenait tellement de la salle de séjour que la personne qui souhaitait lire ou étudier devait probablement se retirer ailleurs, l'homme dans son " antre " peut-être, et la femme dans son boudoir" ; cf. Peter Thornon (1986, p.316).

40. O Dr. Fernando Carneiro utilizaria esta divisão como escritório que comunicava com o armazém dos tecidos através de um pequeno vestíbulo que, por sua vez, apresentava uma segunda escada acessível através do jardim. Deste modo, a a entrada e saída de clientes fazia-se sem que a esfera de trabalho jamais se cruzasse com a da família.

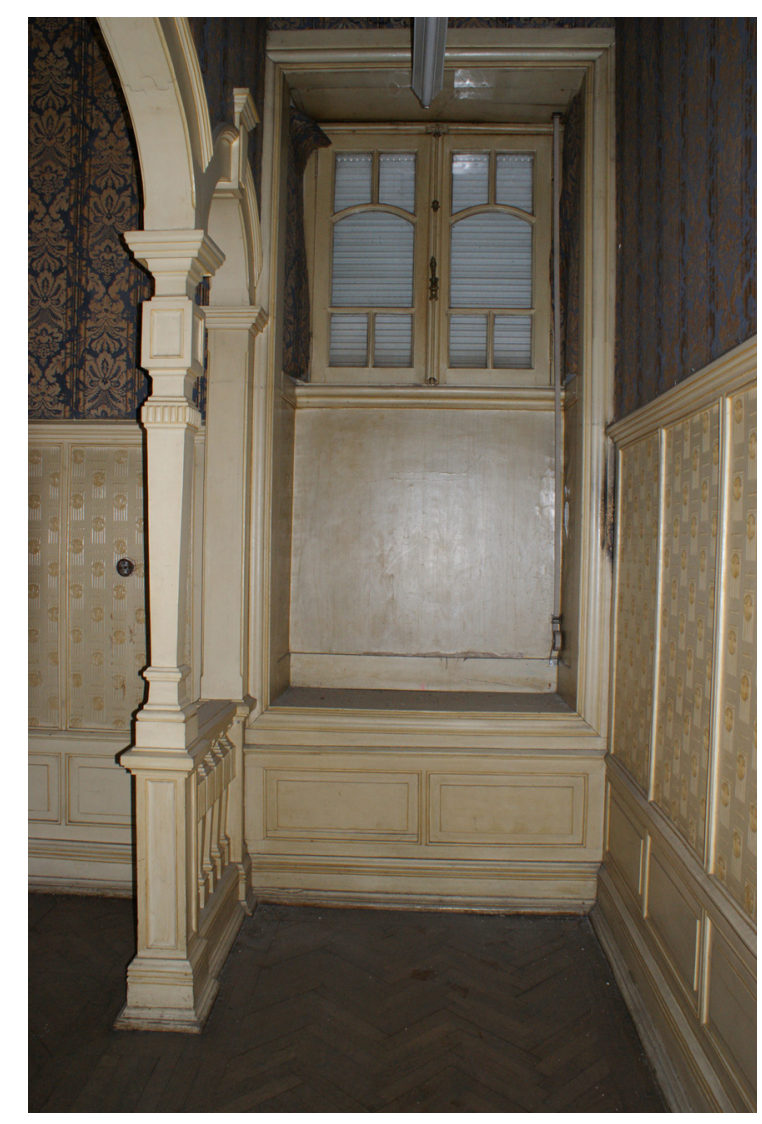

Figura 17 - Recanto do salão. Fotografia de Mónica Romãozinho. onde se retirava quem quisesse ler ou estudar, o homem no seu "antro" talvez, e a mulher no seu boudoir"39 (Figuras 18 a 20).

No piso inferior (planta do subsolo), encontra-se localizada a sala de bilhar, precisamente sob o escritório, mas que na realidade acabaria por assumir mais tarde a função de escritório, eventualmente ainda no tempo de Joseph Bouhon ${ }^{40}$. Uma porta com um pequeno postigo (que não figura na planta) estabelecia a passagem desta divisão para um pequeno corredor ligado a um vestíbulo que, por sua vez, conduzia ao armazém dos tecidos e apresentava uma segunda escada em madeira de acesso ao jardim (Figura 21). $\bigcirc$ pavimento deste pequeno vestíbulo é em mosaicos quadrados pretos, sangue de boi e brancos. A entrada e saída de clientes ocorriam sem que a esfera do trabalho se cruzasse com a esfera da família. Em obra, o lavatório rodaria $90^{\circ}$ no seu posicionamento e o espaço inferior das escadas acabaria por dar lugar a uns arrumos. $\bigcirc$ nicho destinava-se a um sofá, enquanto a área central seria ocupada pela mesa de jogo. O pavimento, em mosaico cerâmico, apresenta flores e acantos enquadrados numa composição geometrizada e assente num paleta de cinzas e azuis animados por contornos a preto.

No mesmo piso e quase simetricamente colocada relativamente à sala de bilhar, situa-se a cozinha, assim como a casa de banho de serviço, que se desdobra em dois compartimentos: o primeiro destinado ao lava-mãos e acessível 
através da cozinha, outro que integra ainda hoje a banheira em pedra lioz e que é acessível através do vestíbulo. Este último destinava-se às criadas, preocupação que começava a assolar alguns projectistas portugueses de então, como Raul Lino:
41. Cf. Raul Lino (1992, p.45).

"Quando o tamanho e categoria da casa o permitam, não devemos esquecer o quarto de banho para as criadas. (...) É fácil neste capítulo estabelecer um mínimo de comodidades pelo menos a água fria e o despejo da tina encanados; para a água quente, onde não a possa haver encanada directamente da caldeira, depressa se transportam uma ou duas cafeteiras desde o fogão da cozinha"41.

A cozinha (Figuras 22 e 23) apresenta-se revestida em toda a altura por ladrilho vidrado, apresentando três secções fundamentais: a mais baixa, delimitada por faixas de ladrilho cinzento e azul (rodapé) e definida no meio por alternâncias de ladrilhos brancos dispostos no sentido horizontal ou vertical; a intermédia formada pelo mesmo tipo de mosaico aplicado horizontalmente; a cimalha, constituída por uma faixa de azulejos de "Delff". Estes últimos surgem dispostos de modo pontuado e enquadrados por ladrilhos colocados nos sentidos vertical e horizontal, delimitada inferiormente por um friso liso em azul e superiormente por uma cercadura azul composta por motivos fitomórficos mais abstractos. A azulejaria azul e branca, em faiança de "Delft" ou inspirada na mesma, retrata temáticas de um quotidiano doméstico em família ligado ao campo e à pesca. Avós, pais com crianças ou crianças de colo, camponeses ou pescadores, personificam aquelas vivências, correspondendo cada azulejo a uma nova "história" que encantava as crianças da casa já no tempo da família Carneiro. No

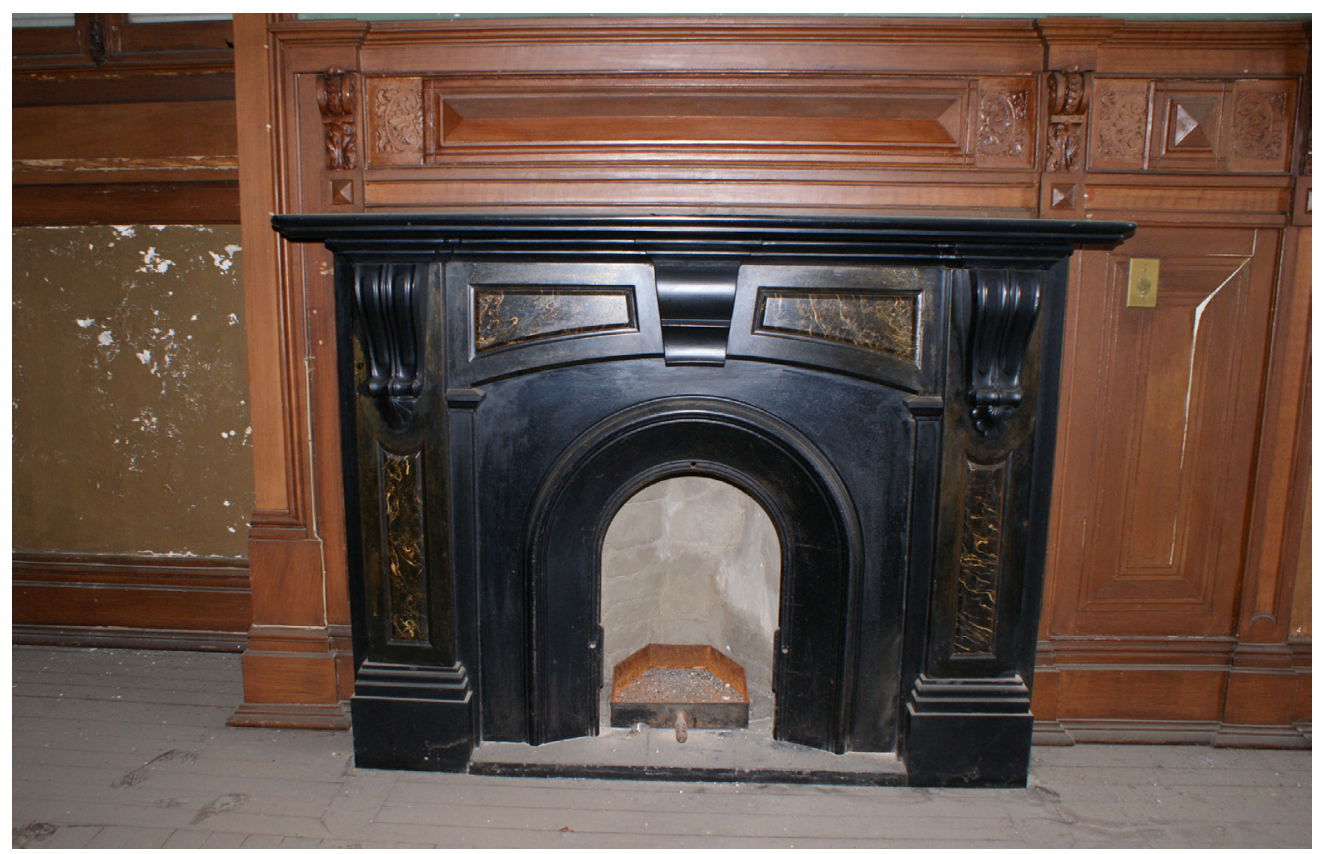

Figura 18 - Lareira do escritório, integrada em lambril estilo Renascença. Fotografia de Mónica Romãozinho. 


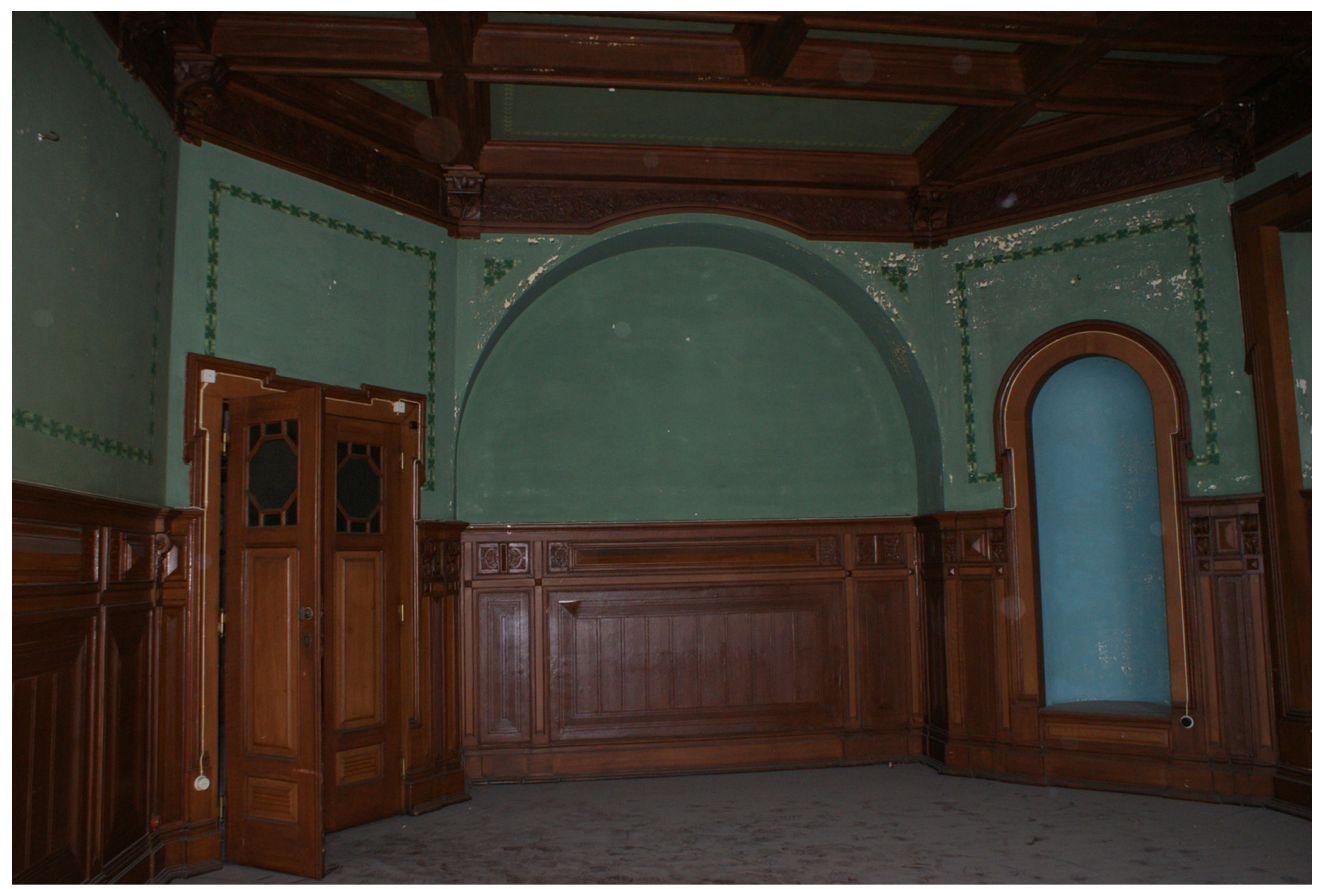

Figura 19 - Vista do escritório e respectivo tecto em caixotões. Fotografia de Mónica Romãozinho.

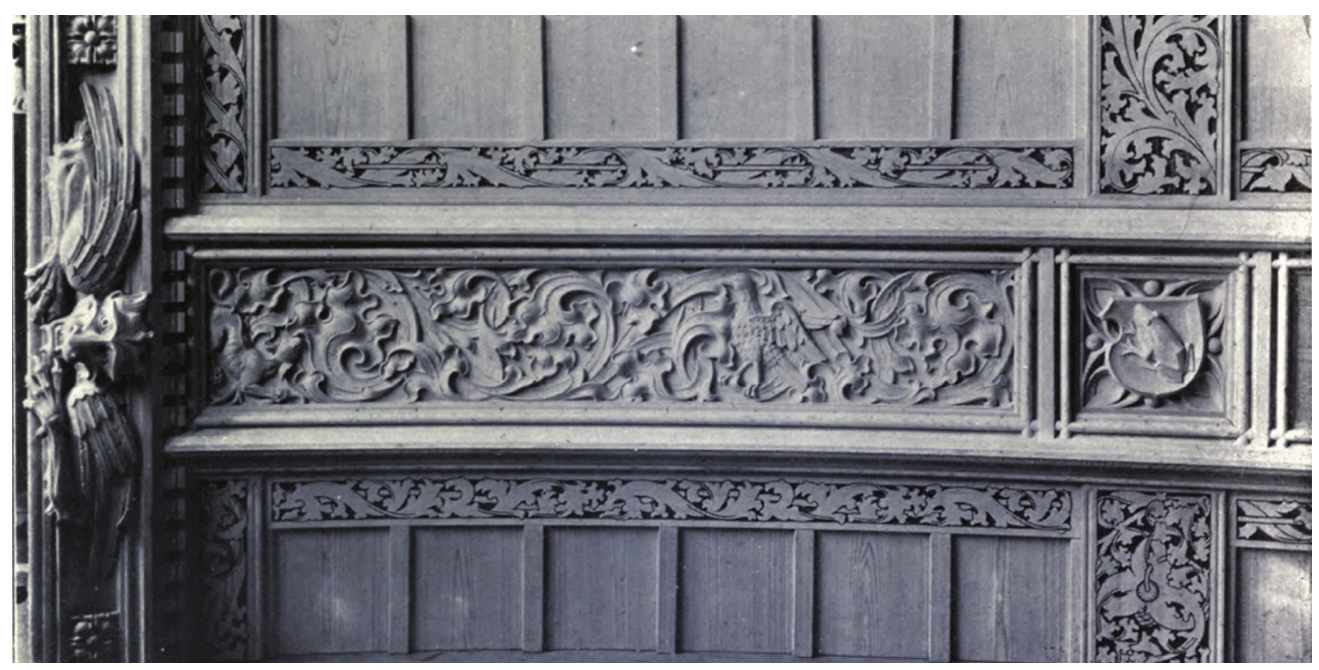

Figura 20 - Decoração de tecto (em relevo). Professor J.Regl., Zurique. Fonte: Academy Architecture and Annual Architectural Review, London, v.23 , p. 144, Jan./June 1913.

projecto original, a cozinha apresentava uma copa de dimensões e localização idênticas às da copa do piso superior, mas na fase construtiva, seria apenas implementado o monta-pratos, com quadrados envidraçados e guarnição em madeira pintada de cinzento, com o telefone e campainha. Foi construído um lava-mãos na mesma prumada do da sala de jantar, com um pequeno armário pintado de cinzento. A cozinha é iluminada por uma composição simétrica de janelas com pequenos 
quadrados envidraçados, em que a janela central assume uma altura mais elevada através da introdução de uma bandeira. $\bigcirc$ pavimento dos nichos das janelas laterais corresponde a um novo tapete de mosaicos policromos, dotado de cercadura. Persiste ainda hoje o forno de lenha e respectiva prateleira que ocupava um dos cantos da cozinha. Existe uma saída para uma conduta vertical junto ao forno o que significa que o calor que este libertava seria rentabilizado no âmbito do aquecimento da água da banheira do WC do piso superior. Lateralmente ao forno, situavam-se barras que sustentavam os talheres de cozinhar, assim como o saleiro. $\bigcirc$ nicho existente na cozinha, que correspondia em planta a uma janela, recebia uma estrutura em traves de madeira onde eram pendurados os tachos, panelas e frigideiras. Uma mesa com tampo de mármore completava este conjunto.

A cozinha encontra-se directamente ligada à dispensa e à rouparia, ambas acessíveis pelo pequeno vestíbulo ligado ao corredor e, no segundo caso, foi também prevista uma acessibilidade directa pelo exterior. Na rouparia, de planta semi-circular e integrada na bow-window, a parede recta incorpora uma fila de armários encimados por vãos em vidrinhos que iluminam e ventilam a despensa. A parede surge revestida pelo mesmo ladrilho branco, mas agora inserido na posição vertical até 1,50 m de altura aproximadamente e rematado superiormente por um friso de azulejaria igual ao do WC social e inferiormente por um rodapé em mosaico branco. $\bigcirc$ pavimento é composto por geometrismos nas cores laranja, castanho e branco. Apesar de, em planta, não existir nenhuma comunicação entre a despensa e a cave, acabaria por ser aberta uma porta que permite aceder a uma estreita escada que conduz à garagem localizada numa segunda cave e não em anexo (situado a Poente) como nos sugerem os desenhos.

espaço privado começa, de certo modo, a adivinhar-se a partir do patamar da escadaria. É precisamente ao nível deste patamar que nos é possível contemplar uma pintura de Eduardo Malta (1900-1967) 42, que retrata um cenário pastoril, temática recomendada pelos tratados e manuais da época (Figura 24). A pintura não corresponde a um elemento pontual que fixamos na parede, mesmo que segundo uma lógica de centralidade ou alinhamento, passando a ocupar toda a parede e tornando-se deste modo mais uma componente integrante do design de interiores como também ocorria na Inglaterra:

O pintor de quadros será o primeiro a admitir que a beleza da pintura depende da relação entre as suas partes; mas se a relação entre uma cor e outra cor é tão importante, a lógica dedução é a de que a pintura em si própria deve depender da beleza da composição de tudo. E encontramos, de facto, nos primórdios da pintura, o pintor no seu melhor como decorador mural. (...) Nesta perspectiva, podemos constatar que as pinturas, numa casa, deveriam possuir qualidades decorativas que façam com que estas se relacionem em harmonia com a composição global da qual fazem parte ${ }^{43}$.

Por outro lado, a própria temática da pintura relacionava-se com as necessidades psicológicas do dono da casa, que retornava a casa após um dia de trabalho nos moldes das sociedades burguesas que se generalizavam na Europa
42. Pintor e retratista nascido na Covilhã Conquistou em 1936 o Prémio Columbano, e no ano seguinte, a medalha de ouro da Exposição Internacional de Paris. Frequentou a Escola de Belas Artes do Porto. Ainda aparentado com o escultor Manuel Morais, e com o escritor Raul Brandão. Fez a instrução primária na sua terra, e, embora a família se tivesse fixado no Porto, foi em 1921 na Covilhã que desenhou os cenários para a revista "o País da Guedelha”. Retratou personalidades como Teixeira de Pascoais Aquilino Ribeiro e Augusto de Castro. Os retratos de Salazar e do Cardeal Cerejeira, da sua autoria, pertencem ao Instituto Nacional de Estatística. O Presidente do Brasil Getúlio Vargas e o político espanhol José António Primo de Rivera, posaram para ele. Escreveu as obras $\mathrm{Do} \mathrm{Meu}$ Ofício de Pintar e Retratos e Retratados. Disponível em: http://www.cmcovilha.pt/simples/?f=2395. Acesso em: 15 maio 2011.

43. "The picture painter will be the first to admit that the beauty of the picture depends on the relation of its parts; but if the relation of one colour to another is so important, the logical inference is that the picture itself must depend for its beauty in the scheme of things. And so one finds in the earlier ages of painting the painter at his best was a wall decorator.(...) Pictures, then, in the house, it may be said, should possess a decorative quality which should be brought into harmony with the whole scheme of which they form a part"; cf. M.H. Baillie Scott (1906, p.5253). 
44. "The desired goal, simply stated, was the creation of a pastoral realm for physical and mental reflection in which the décor contributed to, rather than detracted from, the refreshing of the weary brain-worker."; cf. Joyce Henry Robinson (2008, p.297).

45. "If we imagine, for instance, the tired man of business returning to his suburban home in the evening, it can hardly be supposed that he will be prepared to make the special mental effort involved in an inspection of his pictures; but whatever decorative quality they express in conjunction with
Ocidental: A meta desejada, simplesmente estabelecida, era a criação de um reino pastoral para o relaxamento físico e mental em que o decor contribuiria para, mais do que cansar, o refrescar do cérebro cansado do trabalhador ${ }^{44}$. $O$ universo do trabalho era então uma questão do domínio masculino e cabia à dona de casa, responsável pela decoração, garantir a harmonia e tranquilidade no lar:

Se nós imaginarmos, por um instante, o homem de negócios cansado retornando à sua casa de subúrbios no final do dia, dificilmente se esperará que esteja preparado para desenvolver um esforço mental especial na análise dos seus quadros; mas qualquer que seja a qualidade decorativa que expressam em conjunto com a sua envolvente, irão pelo menos envolvê-lo numa atmosfera que transmite doçura e charme como uma música harmoniosa ${ }^{45}$.

tecto correspondente à escadaria, em estuque pintado de branco, apenas visível ao olhar de quem sobe em direcção ao piso dos quartos, consiste numa moldura percorrida por uma sucessão de linhas e rematada em ambos os topos por semi-círculos que demarcam o eixo central do tecto e que aparecem ladeados por pequenas contra-curvas.

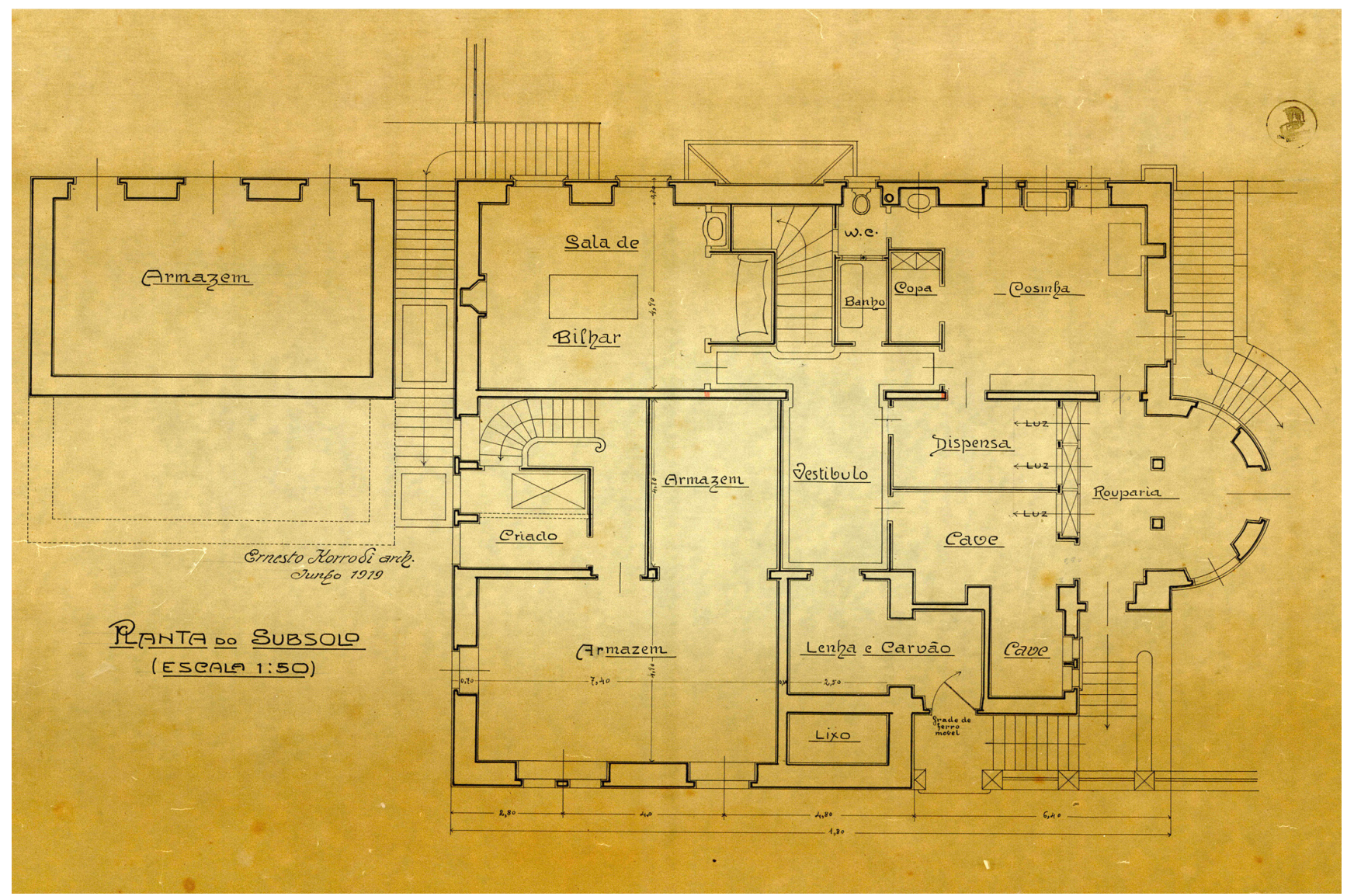

Figura 21 - Planta do primeiro subsolo: versão quase final apesar de alguns desajustes relativos ao construído. Acervo do Arquivo Distrital de Leiria. 


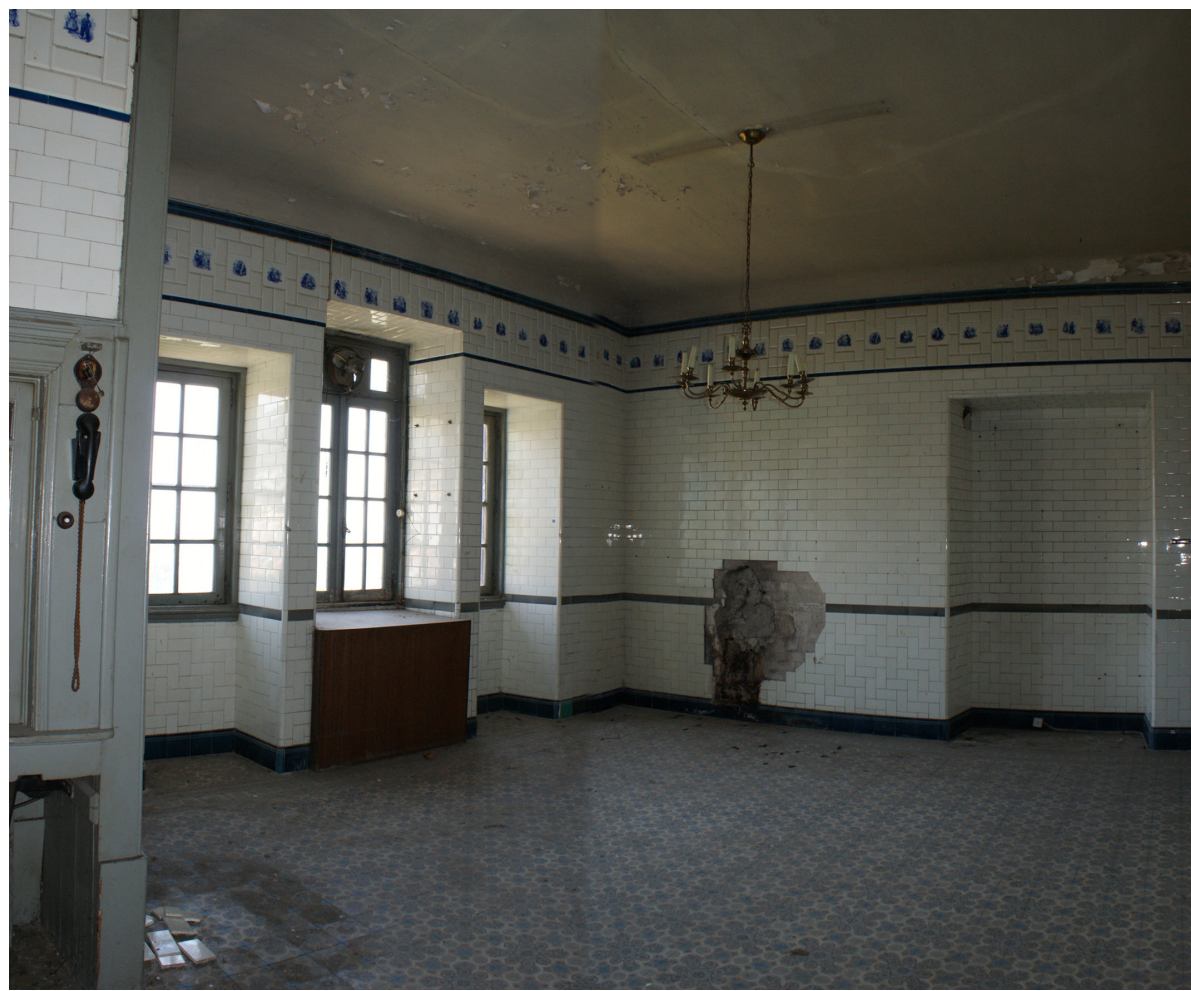

their surroundings will at once enfold him as in an atmosphere which soothes and charms like harmonious music."; cf. M.H. Baillie Scott (1906, p.53).

Figura 22 - Vista da cozinha. Vê-se o monta-pratos em primeiro plano (lado esquerdo). Fotografia de Mónica Romãozinho.

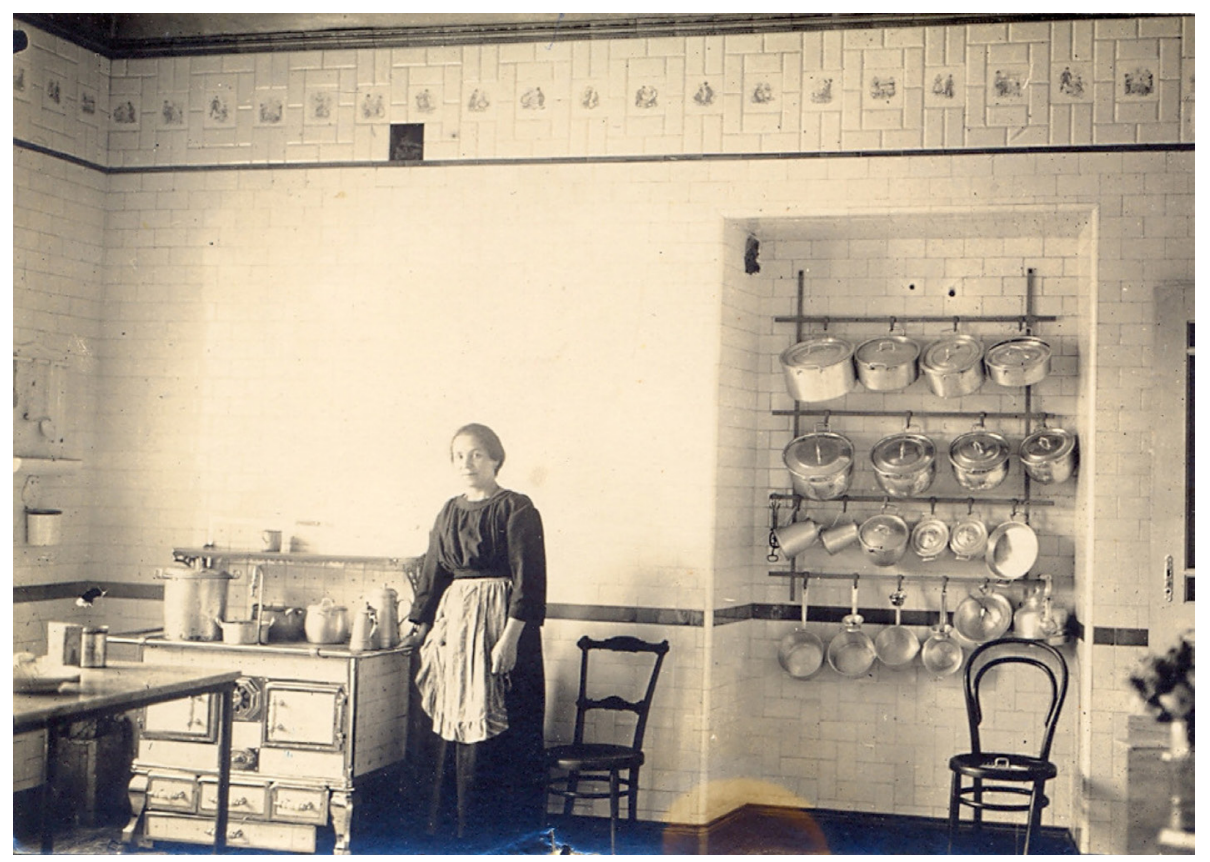

Figura 23: - Interior da cozinha, na qual se encontra Maria Rita, criada que trabalhara 20 anos para a família Bouhon. Coleção privada de João Korrodi.

Annals of Museu Paulista. v. 21. n.2. Jul.-Dec. 2013. 
A supressão quase geral de todo o ornamento aproxima esta solução das propagadas quer pelos progressistas austríacos e alemães quer pelos franceses inspirados pelo estilo Império. A luminária de parede, em ferro, não integra mais as tulipas de vidro ou globos, mas subsiste a sua serralharia Arte Nova, composta por linhas ondulantes e folhagens assimétricas (Figura 25). Contudo, é invulgar a introdução de uma janela geminada em madeira escurecida, associada a um ponto poético de contemplação da escadaria principal. $O$ próprio arco abatido que une os dois arcos de volta perfeita das janelas, apresenta novamente uma sucessão de frisos que atravessam as paredes, formando uma sanca de altura considerável e suscitando, ao mesmo tempo, uma continuidade de linguagem em relação às linhas da moldura do tecto. Porém, a planta sugeria um vão tripartido de largura equivalente à do janelão (Figuras 26 e 27).

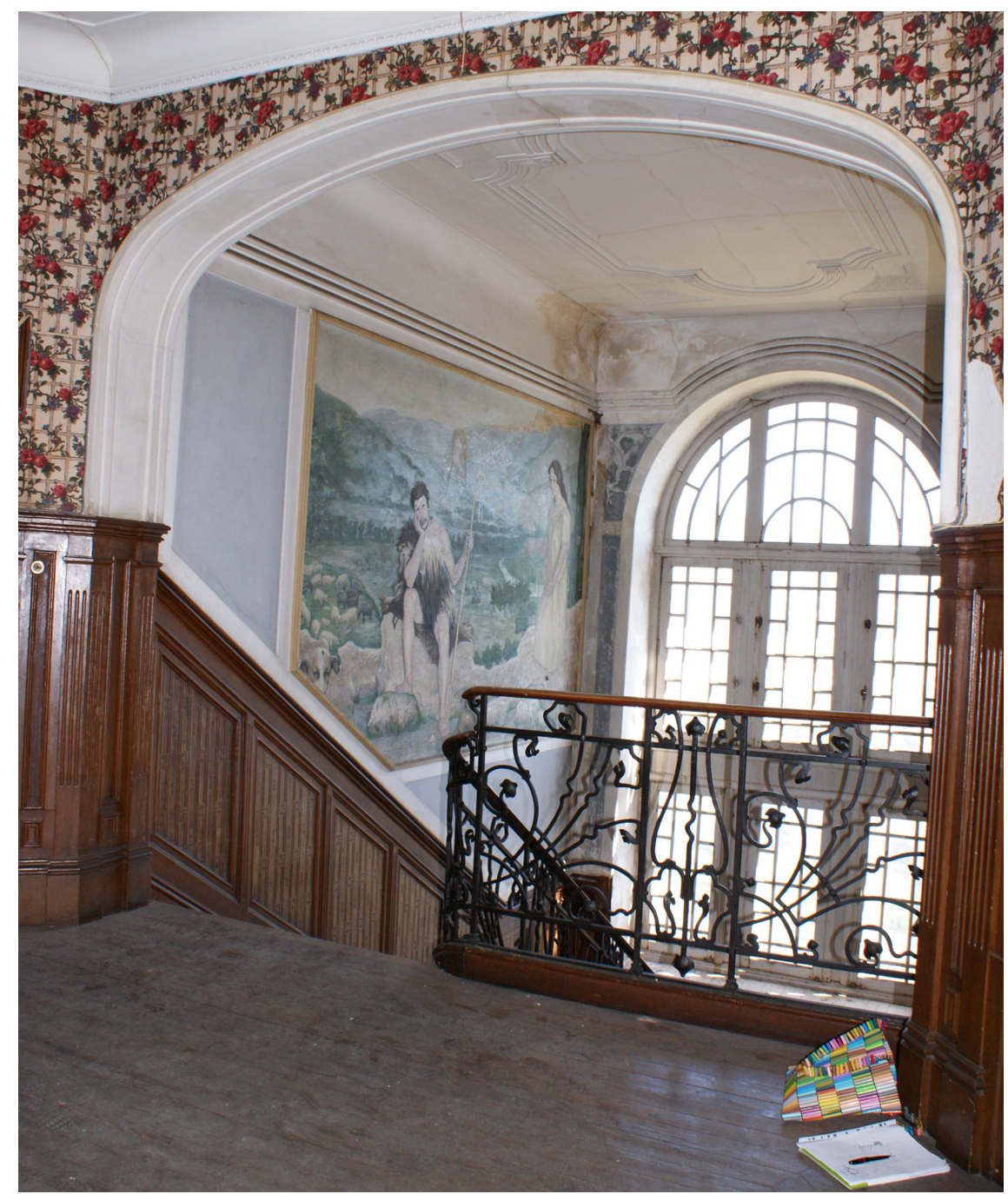

Figura 24 - Patamar de chegada. À esquerda: Quadro de Eduardo Malta.Fotografia de Mónica Romãozinho. 


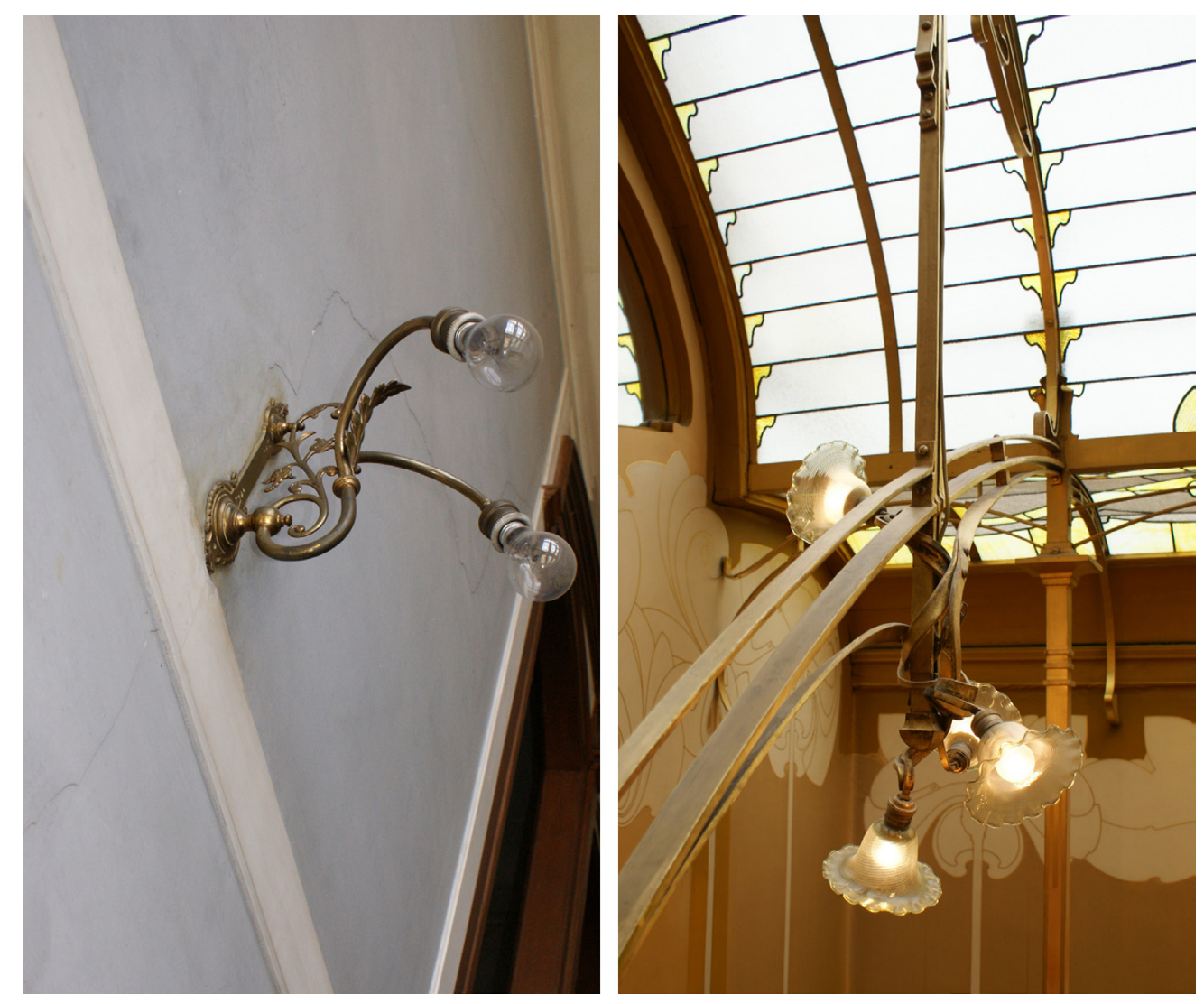

Figura 25 - Luminária do hall, similar a outros modelos internacionais, de que é exemplo a luminária na Casa de Victor Horta, Bruxelas, 1898 (à direita). Fotografias de Mónica Romãozinho.

Como fora referido anteriormente, o hall assume aqui a sua forma completa de um octógono e o seu tecto segue a mesma técnica e linguagem do tecto da escadaria, embora os frisos sejam complementados por conchas explodidas e festões e apresente, neste caso, um elemento central constituído por uma roseta e por alinhamentos radiais que recebe a luminária. As rosas continuam a constituir um elemento decorativo dominante no tema do papel de parede (rosas vermelhas e azuis) que, à semelhança dos frisos dos tectos da área social, se enquadram no movimento Arts and Crafts, como pudemos constatar assim que comparámos o padrão em causa com outro da autoria de William Morris, o padrão Trellis. Quer - lambril quer as portas com os seus lintéis de remates quadrangulares, seguem novamente um estilo Renascença. O lambril é dominado pela sucessão de pilastras nervuradas e revestido por papel em cor neutra. $\bigcirc$ pavimento em soalho não obedece a nenhuma composição em particular, revelando apenas uma cercadura que acompanha a forma do hall.

Os pavimentos das restantes dependências seguem a mesma solução construtiva, mas sem molduras envolventes. No lado interno das dependências, as molduras das portas simplificam-se e a cor natural da madeira é substituída por 

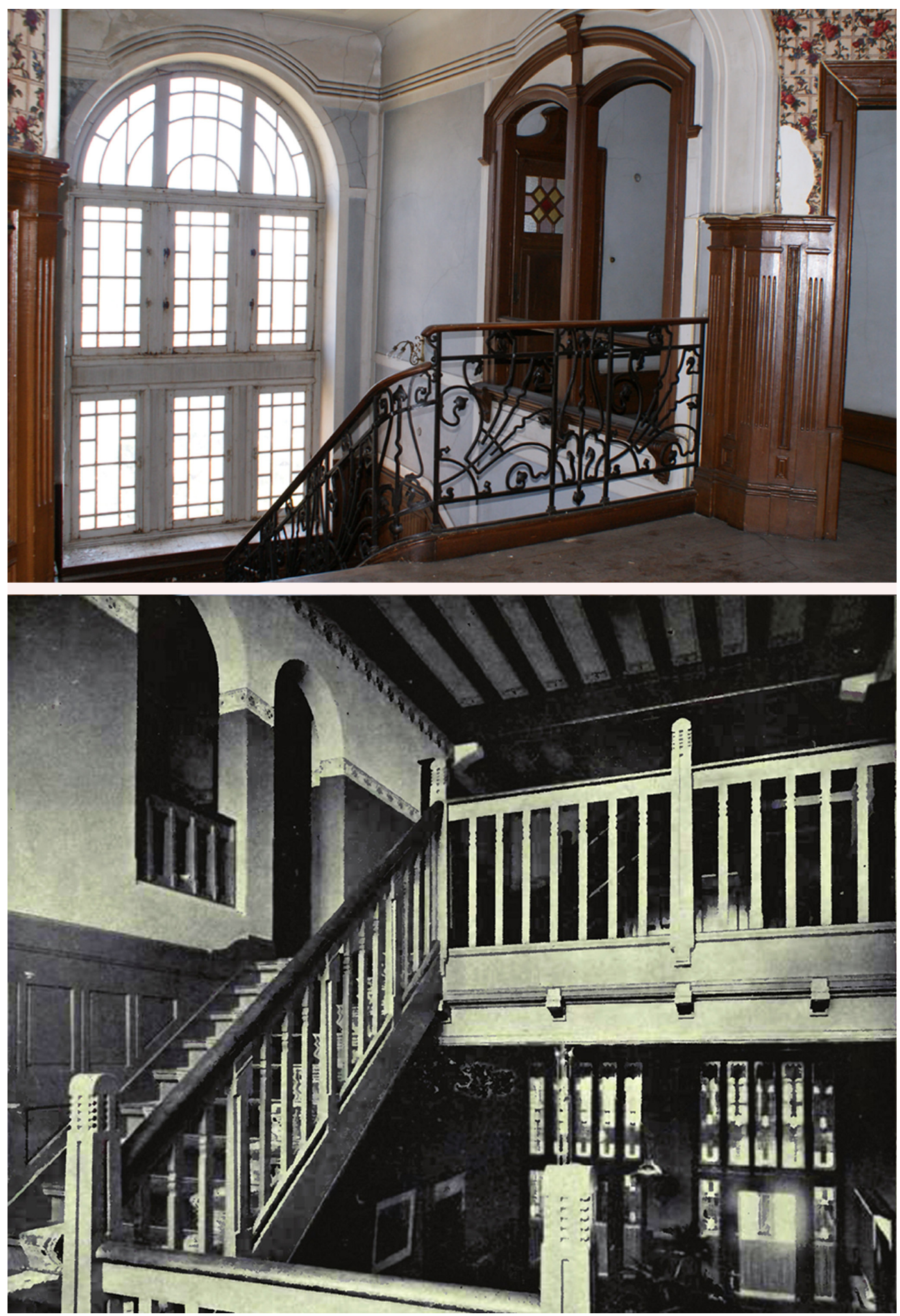

Figura 26 - Vista do hall do piso dos quartos e respectiva loggia. Fotografia de Mónica Romãozinho. Exemplo semelhante de hall com janela geminada, contextualizado em interior da autoria de Ed. Cuypers. Fonte: Academy Architecture and Annual Architectural Review, London, v.44 p. 136, july/dec. 1913. 




Figura 27 - Planta do segundo pavimento à escala 1:50. Acervo do Arquivo Distrital de Leiria.

acabamentos em branco ou por um jogo cromático de marfim e ocre. Há sempre um sentido de diferenciação ou hierarquização entre espaços de passagem e espaços mais íntimos. À semelhança do que acontecera com a planta do piso social, mais uma vez Korrodi propõe a localização precisa de todas as peças de mobiliário essenciais para cada actividade ou tarefa.

quarto dos donos da casa ocupa uma localização privilegiada, pois não só usufrui de uma orientação solar a sudeste, usufruindo-se deste modo do nascer do sol, mas também integra a varanda semi-circular que se sobrepõe à bow-window da sala de jantar. Reunia fundamentalmente todos os requisitos necessários em termos de área, iluminação natural e ventilação, segundo ditames em voga na época: "A condição essencial para que um quarto de dormir seja 
46. "La condition essentielle, pour qu'une chambre à coucher soit saine, surtout quand on doit l'habiter à deux, c'est qu'elle soit vaste et spacieuse, bien éclairée et bien aérée ; que l'air puisse s'y renouveler facilement. On doit éviter les alcôves, qui ont l'inconvénient de diminuer la masse d'air respirable pendant la nuit." ; cf. Ris-Paquot (1894, p.206).

47. Acreditamos que Baillie Scott estaria na génese daquilo que Madsen classifica de Proto-Arte Nova e que os seus trabalhos correspondem a verdadeiros projectos Arte Nova que se anteciparam aos de Victor Horta. O modo como interpreta o ornamento orgânico como elemento plástico capaz de interligar superfícies e mobiliário, fazem de Baillie Scott um verdadeiro precursor da Arte Nova e também uma referência para os progressistas alemães.

48. Cf. M.H. Baillie Scott (1897). saudável, sobretudo quando é ocupado por duas pessoas, é que este seja vasto e espaçoso, bem iluminado e bem arejado: que o ar se possa renovar facilmente. Devem-se evitar as alcovas, que têm o inconveniente de diminuir a massa de ar respirável ao longo da noite" 46 . Nesta mesma perspectiva, uma reentrância, situada entre as duas portas de acesso, destina-se à cama e a duas mesas-de-cabeceira colocadas simetricamente.

Já Mackay Hugh Baillie Scott (1865-1945) 47 sugeria que se abandonasse a solução da cama em ferro trabalhado ou em latão moldado, constatando que esta deveria ser, sempre que possível colocada num recesso, ou pelo menos numa posição em que parecesse uma parte integrante do quarto ${ }^{48}$. $\bigcirc$ vão tripartido é similar ao que ilumina e ventila quer a cozinha quer a sala de almoços (Figura 28). $\bigcirc$ plano inferior das janelas apresenta-se revestido a apainelado almofadado que dá continuidade ao das portadas quando fechadas. Por outro lado, a colocação da cama em frente à janela evitava receber o ar que entra pelas frestas e permitia
Figura 28 - Vão tripartido que ilumina o quarto dos pais. Fotografia de Mónica Romãozinho.

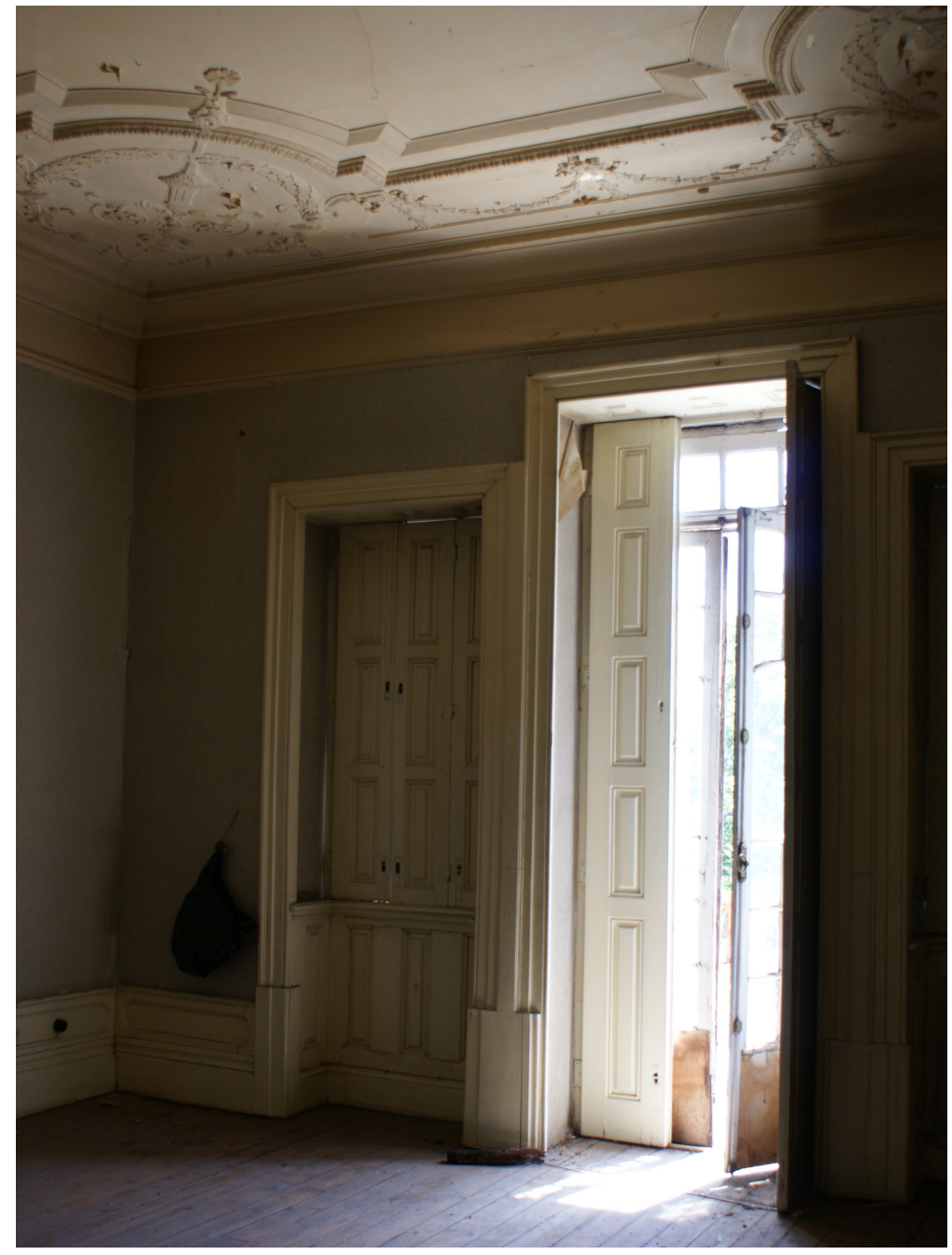


receber luz quando se pretendesse ler ${ }^{49}$. A planta sugeria ainda a localização de um sofá e de várias cadeiras, situação que se repetirá nos outros quartos e que demonstra que estes continuavam a assumir, ainda nesta altura, uma função de estar. Um grande guarda-fato, uma cómoda e um armário integrado no vão central, eventualmente um toucador (que daria lugar a uma janela de sacada) a fim de que houvesse luz suficiente para a senhoras se pentearem, completam este conjunto. As portas e guarnições de madeira estão pintadas de branco, contrastando mais uma vez com as paredes, neste caso cobertas de branco. $\bigcirc$ tecto, referenciado fundamentalmente no Estilo Império, apresenta grinaldas nos quatro cantos, formadas por folhas de louro e acantos que circunscrevem uma composição formada urnas com flores e novamente acantos. Frisos constituídos por uma sequência de linhas ou por óvulos e dardos, emolduram o tecto que apresenta um motivo central com flores e uma bordadura também composta por alinhamentos paralelos. $\bigcirc$ quarto era, aliás, uma das dependências onde o leque de estilos variava mais, de acordo com a moda de então: "Todos os estilos se acomodam na perfeição para a decoração de um quarto de dormir, desde do gótico, a Renascença, o Luís XIV, o Luís XV, o Luís XVI até ao estilo Império" 50 .

No gabinete de toilette, o gomil e a bacia dão lugar a um armário lavatório. Encontra-se revestido a ladrilho vidrado marfim, com um friso de azulejaria Arte Nova, idêntico ao do WC social. Dada a profundidade das peças de mobiliário, tudo indica que Korrodi optou por dois guarda-fatos, que permitem a separação do vestuário do casal, restando uma peça que certamente corresponderia a um toucador. Um sofá, não uma chaise longue como era habitual em França, completa este conjunto. $\bigcirc$ Gabinete de toilette assume, como na França, um duplo papel: "Ele é um dos signos do estatuto do habitante e também da sua ligação à limpeza, elemento de respeitabilidade. Não é uma dependência de serviço, muito menos um espaço funcional" 51 . Deparamo-nos com uma única toilette: "Parece, segundo os raros tratados de savoir-vivre que abordam esta questão, que a maior parte utiliza o gabinete de toilette das suas esposas, de manhã antes delas. No entanto, cada um dos cônjuges tem o seu serviço especial sobre a mesma mesa de toilette" 52 . A toilette encontra-se ligada ao quarto dos donos e tem também acesso directo pelo pequeno vestíbulo iluminado pelos arcos geminados. Na viragem do séc. XIX para o séc. XX, a ligação entre quarto e casa de banho torna-se um princípio, relembrando a disposição do séc. XVIII em que em torno do quarto se reuniam as várias dependências. Contudo, estas opções decorrem cada vez mais do desejo de conforto e funcionalidade e menos da vontade de exibir simplesmente um estatuto social, associado à quantidade destes compartimentos complementares. A Condessa de Gencé reconhece que a sala de banho ligada ao gabinete de toilette

\footnotetext{
"facilita o serviço e representa inapreciáveis comodidades, pois assim que se sai da dependência afectada à higiene do corpo, a toilette é terminada sem que se tenha perdido tempo nem apanhado frio ao passar para outro lugar ${ }^{53}$. Toilette, banhos e WC formam então uma verdadeira entidade, não justificada pela aproximação de funções, mas sim, da bem mais material que diz respeito à conduta de água"54
}

49. Ver Monique Eleb e Anne Debarre (1995, p.156).

50. "Tous les styles $\mathrm{s}$, a c c o m m o d e $\mathrm{n} \mathrm{t}$ parfaitement pour la décoration d'une chambre à coucher, depuis le gothique, la Renaissance, le Louis XIV, le Louis XV, le Louis XVI jusqu'au style Empire."; cf. Ris-Paquot (1894, p.197).

51. "Il est un des signes du statut de l'habitant et aussi de son rapport à la propreté, élément de la respectabilité. Il n'est pas une pièce de service et encore moins un espace fonctionnel" ; cf. Monique Eleb e Anne Debarre (1995, p.224).

52. "Il semble, selon les rares traités de savoir-vivre qui abordent cette question, que la plupart d'entre eux utilisent le cabinet de toilette de leur épouse, le matin, avant elle. Cependant, chacun des époux a son service spécial sur la même table de toilette." ; cf. Monique Eleb e Anne Debarre (1995, p.225).

53. “(...) facilite le service et présente d'inappréciables commodités puisque, lorsque l'on sort de la pièce affectée à tous les soins du corps, la toilette est terminée sans qu'il y ait à perdre de temps ni à prendre froid pour passer dans un autre local" ; cf. Comtesse de Gence (1909, p.25). A Condessa de Gencé também escreveria a obra Tratado de Civilidade e Etiqueta (1909).

54. "Toilette, bains, w.c. et cuisine forment alors souvent une véritable entité, non justifiée par le rapprochement des fonctions, mais par celui, plus matériel, des conduites d'eau" ; cf. Monique Eleb e Anne Debarre (1995, p.417). 
55. Em 1897 casou-se com Henriette Lecloux, também belga. Joseph e Henriette tiveram dois filhos na Covilhã: Emma (1900-1989) e Camilo (1902-1980). Henriette faleceu e Joseph voltou a casar em 1905 com uma prima, Virginie Marguerite Lemouche e deste casamento nasceriam Susana e Augusto. Informação gentilmente cedida pelo Eng. Miguel Ritto, bisneto de Korrodi e de Joseph Bouhon.

56. Encontrámos motivos similares numa pintura de Van den Abeele que retrata o interior da Villa Paolina em Viareggio, propriedade que Paolina Borghese deixou em testamento ao seu sobrinho Luís Napoleão (mais tarde Napoleão III) que a cedeu à sua irmã Zenaïde; ver Mario Praz (2008, p.215).

57. Ver Monique Eleb e Anne Debarre (1995, p.315).
No WC, destacam-se os azulejos de linguagem neoclássica, que apresentam uma composição policroma formada por medalhões, festões, rosas e malmequeres e rematada superiormente por um friso idêntico ao do WC social, com dois motivos dominantes, a roseta e as folhas enroladas, mas neste caso em azul claro. $\bigcirc$ banho apresenta um nicho original de forma semi-circular que se destinava a receber a plataforma circular do duche (Figuras 29 a 31 ). De acordo com os actuais proprietários, as loiças sanitárias apresentariam ornamentos florais relevados. Ao fundo do compartimento, localiza-se a banheira. Um sofá e uma mesa de encosto completavam o conjunto de mobiliário. Quer a azulejaria do banho, com as suas glicínias, quer os puxadores utilizados em todo o piso são Arte Nova, à semelhança dos das portas envidraçadas do piso inferior, obedecendo também a um processo de sintetização profunda que os aproxima dos modelos difundidos na Alemanha. $\bigcirc$ modelo de toalheiro de cristal com ferragens em níquel seria, do mesmo modo, aplicado nas toilettes dos quartos e nas casas de banho do palacete.

$\bigcirc$ quarto da filha, Susana Bouhon, embora seja o menos espaçoso de todos, surge complementado por um boudoir (Figura 32). $\bigcirc$ quarto integraria a cama e respectiva mesa-de-cabeceira, um sofá, um guarda-fato e, por fim, uma cómoda ou toucador. A meia-irmã, Emma (1900-1989), casara-se em 1919, o que explica a ausência do seu quarto ${ }^{55}$. Em obra, o quarto acabaria por ser estreitado, dando origem a um recesso revestido a azulejaria com um lavatório incorporado /sendo suprimido o previsto para o boudoir), à semelhança do que acontece com os outros quartos. A linha formal dos azulejos do friso, pela sua abstracção e pelo recurso ao dourado sobre branco, leva-nos a acreditar que advêm novamente da fábrica belga referida anteriormente. No tecto, Korrodi recorre às mesmas grinaldas que encontrámos no tecto do quarto dos donos, colocadas simetricamente e enquadradas em círculos definidos por contornos lineares ou frisos com óvulos e dardos. Dada a omissão do dourado e a simplicidade dos frisos nervurados assim como o motivo central do tecto, de influência oriental (chinoiserie), em forma de leque, constatamos que este tecto evoca o estilo Império 56 .

$\bigcirc$ boudoir, lugar de socialização feminina e qualificado de frívolo ao longo do século XIX, reaparece na viragem do séc. XX, mas unicamente na habitação de luxo ${ }^{57}$. Neste caso, assume uma localização privilegiada no ângulo do edifício e integra uma secretária destinada à escrita, a respectiva cadeira, o toucador e uma poltrona ou uma bérgere. Na varanda, encontramos painéis de azulejaria Arte Nova, de forte verticalidade, reforçada pela representação de fitas, gerbérias, folhas e caules invertidos. $\bigcirc$ fundo apresenta uma gradação tonal, que varia desde o azul-escuro ao verde de água, em que as mesmas flores, dispostas de modo profuso no topo dos painéis, se vão libertando e caindo em direcção à tonalidade mais clara.

No quarto dos filhos, Camilo e Augusto, repete-se a solução do tecto em caixotões de madeira mais clara, adoptada no escritório do piso inferior. $\bigcirc$ papel de parede apresenta uma composição mais sintetizada do que o papel que cobre o hall, mais próximo a um estilo vitoriano e eventualmente aplicado posteriormente, já no tempo da família Carneiro. Neste caso, o desenho centra-se numa sucessão de rosas 


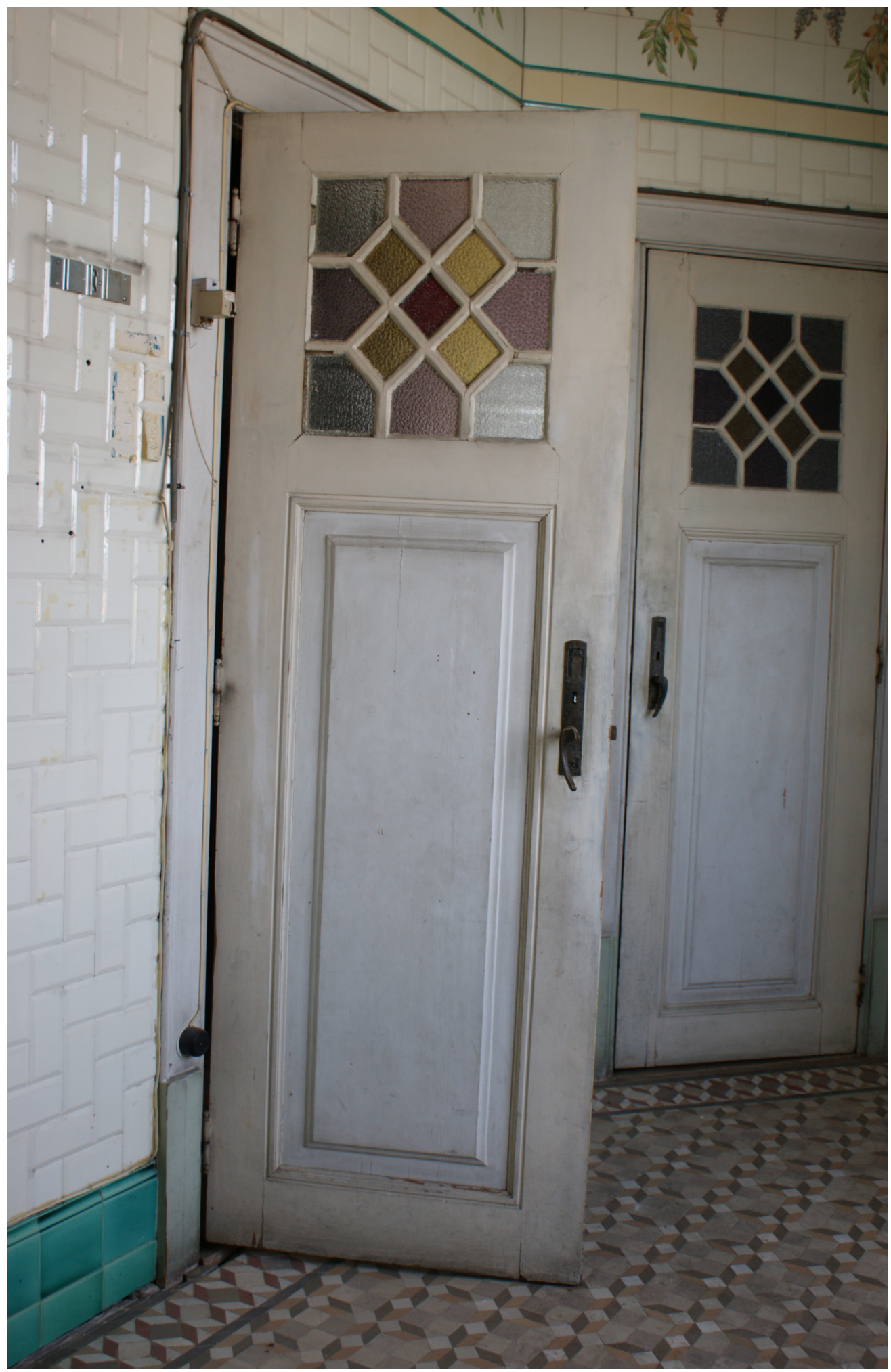

Figura 29 - Entrada da casa de banho completa. Fotografia de Mónica Romãozinho.

Annals of Museu Paulista. v. 21. n.2. Jul.-Dec. 2013. 


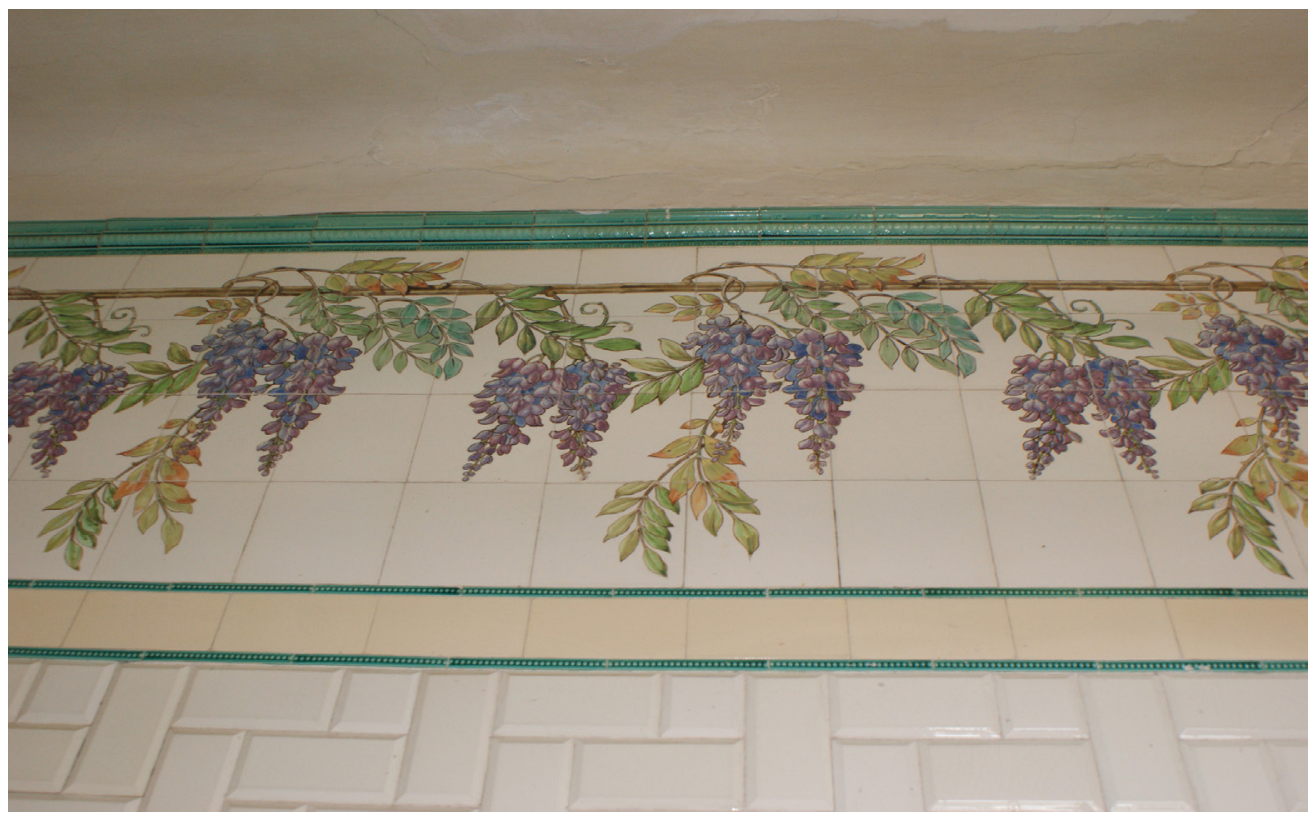

Figura 30 - Pormenor da azulejaria da casa de banho. Fotografia de Mónica Romãozinho.
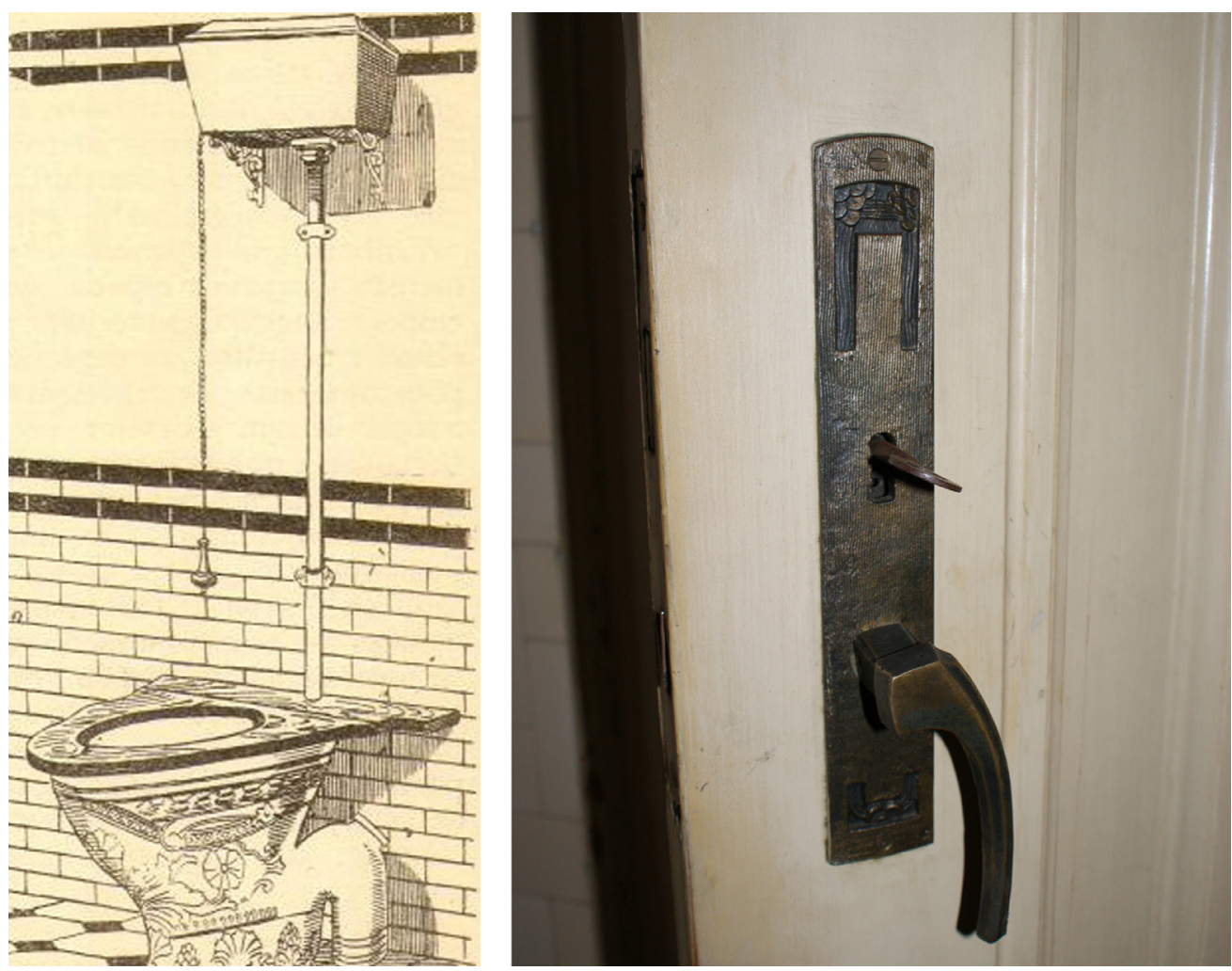

Figura 31 - Exemplo de loiça sanitária com pormenores decorativos. Fonte: A Construcção Moderna, Lisboa, Anno VII, n.21 1, p.505, 20 jan. 1907. À direita: manípulo Arte Nova na Casa Bouhon. Fotografia de Mónica Romãozinho. 
e lírios azuis enquadrados numa malha de fitas entrelaçadas. Korrodi criou novamente uma reentrância, localizada entre as portas, que se destina a receber as duas camas simples. $\bigcirc$ canto residual resultante de um dos chanfros da dependência seria equipado com um lavatório e um armário que ocupa o espaço sobrante inferior à escada, revelando certas preocupações higienistas transversais a todos os aposentos (Figura 33). O lavatório enquadra-se no estilo Arte Nova, devido aos seus suportes em ferro que apresentam movimentos ondulantes (Figura 34).

$\bigcirc$ último quarto, o de hóspedes, apresenta-se iluminado por mais um vão tripartido e revestido a papel cinzento no caso do lambril e florido ao nível da restante parede. $\bigcirc$ desenho do tecto aproxima-se da linguagem dos da escadaria e do hall, mas aqui o ornamento floral é totalmente abolido. Korrodi parece ter seguido, mais uma vez, as tendências que se faziam sentir desde os finais do séc. XIX, prevendo a colocação de duas camas, mesa de cabeceira, cadeiras ou fauteuils, uma cómoda, uma secretária com o respectivo assento, um guarda-fato e uma mesa (simples ou de toilette) ${ }^{58}$. Integra também uma zona com lavatório que,



Figura 32 - Quarto da filha. Vê-se o acesso ao boudoir e a zona de lavatório. Fotografia de Mónica Romãozinho.
58. "Un bon lit, une table de toilette formant commode, un secrétaire, une table, deux fauteuils, plusieurs chaises, un tapis, une garniture de cheminée, voilà son ameublement complet." ; cf. Ris-Paquot (1894, p.211). 
à semelhança dos outros, corresponde ao modelo de origem e surge sustentado em dois perfis de ferro.

Do hall octogonal, parte a escada de serviço em direcção ao sótão, onde se localizam as dependências de apoio ao pessoal doméstico da casa. A dependência mais valorizada ao nível do sótão corresponde ao quarto da professora, localizado acima da escadaria e iluminado por um lanternim que garante um pé-direito mais elevado. O quarto, anteriormente referido, integra um vão tripartido que dá acesso a uma pequena varanda orientada a tardoz. Esta dependência é visível na secção transversal $A-B$ que nos mostra inclusivamente a reentrância chanfrada onde se localizaria a cama (Figura 35). No lado oposto, encontra-se o quarto das criadas que surge iluminado por um grande óculo. Outra dependência, sobreposta em relação às zonas húmidas dos pisos inferiores, acolheria o depósito de abastecimento de água e uma latrina em madeira que se destinava às criadas. Por fim, costurava-se num último compartimento e por vezes no patamar de chegada ao sótão.

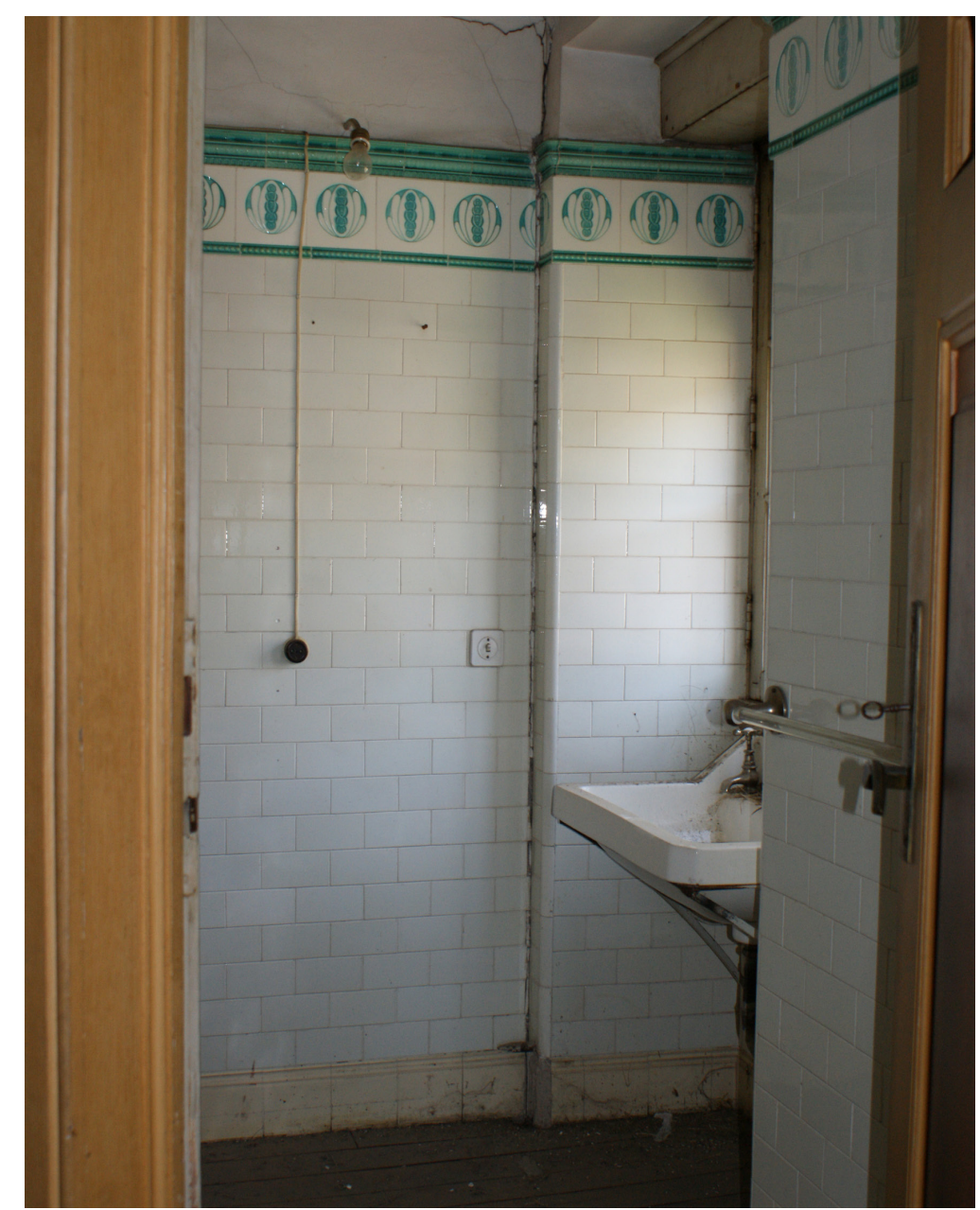

Figura 33 - Vista da toilette ligada ao quarto dos filhos. Fotografia de Mónica Romãozinho. 

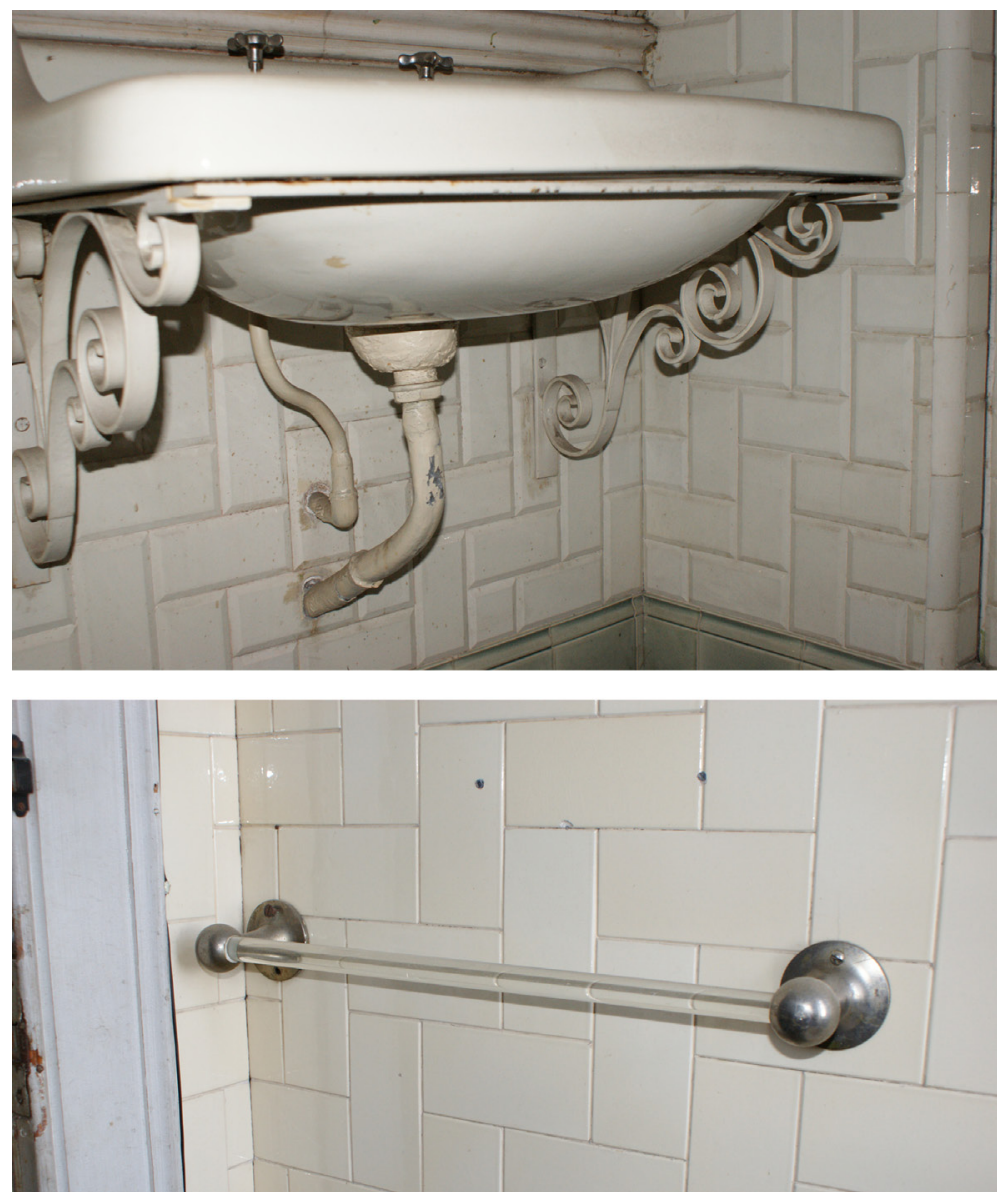

Figura 34 - Lavatório integrado nas toilettes dos quartos, com suportes em ferro trabalhado. Toalheiro em cristal que surge aplicado nas mesmas dependências e no wc. Fotografias de Mónica Romãozinho.

\section{Conclusões}

processo de obra, consultado no Arquivo Distrital de Leiria, é vasto e inclui plantas dos pisos principais já com a localização específica de todo o mobiliário, não apenas das peças fixas, e que corresponde, neste sentido, a uma verdadeira planta de design de interiores na medida em que Korrodi procedia à cotagem de todo o mobiliário, não só da cozinha ou do WC, mas também mesas ou armários de diversas tipologias. Os próprios desenhos evidenciavam já uma definição rigorosa de todos os espaços interiores e respectiva colocação de mobiliário, revelando uma preocupação com a funcionalidade desses mesmos, com a exploração de novas relações espaciais, conforto, iluminação ou ventilação e com a própria estandardização de materiais e acabamentos escolhidos. Korrodi dedicou uma especial atenção à pormenorização dos respectivos interiores através da execução de cortes detalhada mapas de vãos e desenho de mobiliário. 


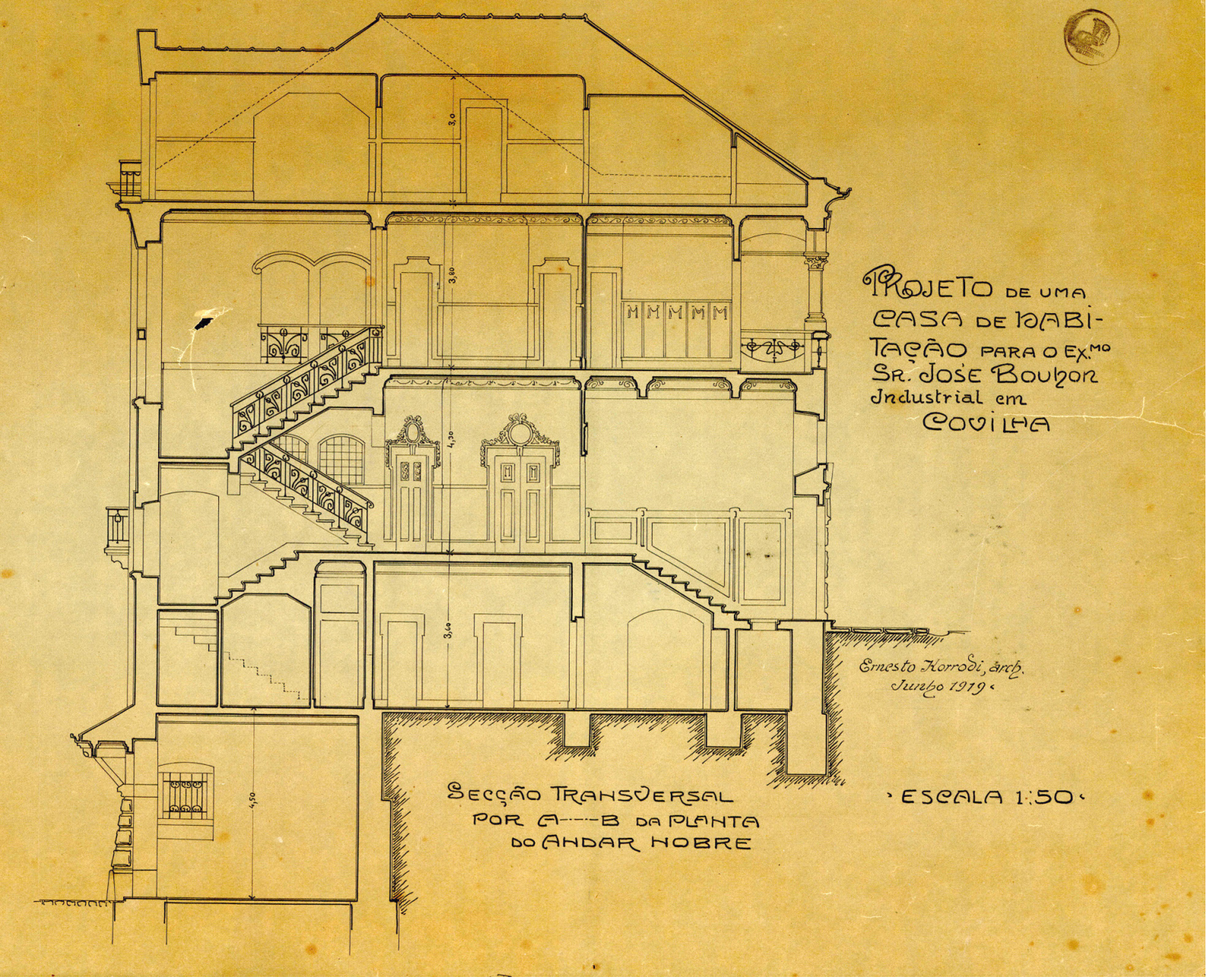

Figura 35 - Corte transversal A-B, à escala 1:50. Acervo do Arquivo Distrital de Leiria.

No âmbito dos espaços interiores, é sobretudo assinalável o modo como o autor aborda as várias soluções decorativas e a paleta cromática, atribuindo tratamentos diferenciados de dependência para dependência. Mesmo no contexto da Primeira República portuguesa, assistimos a uma certa persistência de determinadas dependências e hierarquias espaciais assim como à distinção dos papéis do género masculino e feminino, que condiciona a localização das dependências, a sua relação de proximidade ou contiguidade e a caracterização das mesmas. Quer a cor, mais intensa (castanho) ou mais suave (branco, marfim), quer os padrões florais mais ou menos abstractos, mais escultóricos ou planos, contribuem para a clarificação dos espaços ligados à sociabilidade e aos negócios (no caso do género masculino) ou a uma sociabilidade mais privada, educação dos filhos e exigências domésticas (no caso do género feminino). Quer a saleta 
quer o boudoir figuram como espaços de escala mais acolhedora que se destinavam à sociabilidade no feminino. As madeiras são pintadas de branco ou os papéis oleados de casca de ovo no caso da saleta, salão e sala de almoços que correspondem a espaços do domínio feminino e de convívio familiar, mas também nos quartos dos pais e da filha Susana. Em oposição, uma paleta mais escura surge associada ao escritório, à sala de jantar e ao quarto dos rapazes. As opções cromáticas contribuem, do mesmo modo, para a clarificação dos espaços de permanência ou de passagem: os batentes das portas apresentam-se pintados em marfim ou em madeira aparente consoante a divisão com que confinam.

A organização funcional e hierárquica do projecto evoca soluções inglesas publicadas em revistas, da autoria não só de Baillie-Scott, mas também Richard Norman Shaw (1831-1912) ou do escocês Arnold Mitchell (1863-1944), entre outros, presente na valorização de compartimentos meramente funcionais como copas, engomadorias ou rouparias, cozinhas e wc's. A exaltação das varandas abertas sobre os jardins ou do hall como espaço simultaneamente de circulação e de estar, sempre antecedido de uma antecâmara, reflecte igualmente opções seguidas nos cottages ou country houses publicadas pela imprensa internacional. Soluções como bay windows ou bow windows aproximam, do mesmo modo, os interiores dos modelos ingleses, assim como o forte sentido de individualidade e intimidade associado às distintas espacialidade. Entradas e escadas denunciam uma separação entre áreas de circulação destinadas à família ou visitas e pessoal doméstico que resulta da mesma vontade de salvaguardar a privacidade da própria família.

Contudo a Arte Nova impulsionou mudanças significativas ao nível dos seguintes pressupostos: relação de maior fluidez entre as dependências (entre as da esfera da sociabilidade, em particular) ou separação estabelecida através de vastos guardaventos em arco abatido; aproximação entre dependências até então dissociadas (entre a cozinha e a sala de jantar, por exemplo); integração e valorização de compartimentos funcionais como as copas de apoio, as casas de banho ou a própria cozinha. No presente caso, assistimos a uma forte interligação entre salas de refeições, à substituição de corredores por amplos vestíbulos e observam-se compartimentos mais amplos resultantes do recurso a uma estrutura mista, composta por vigamentos de betão. Os próprios gabinetes de toilette dos donos da casa fundem-se num só compartimento, denunciando uma mentalidade mais aberta por parte do cliente e constrastando com a divisão segundo o género habitualmente presente em outras encomendas, inclusivamente no contexto da habitação colectiva de que é exemplo o prédio de rendimento de Mendonça \& Costa, situado na Rua Braancamp em Lisboa (1914).

Alguns destes interiores testemunham não só programas de interiores e opções construtivas e estéticas que acompanham os padrões de gosto internacional, como incorporam componentes tecnológicas inovadoras que davam resposta ao desejo de conforto, designadamente os elevadores. Na Casa da família Bouhon, multiplicam-se os compartimentos destinados aos serviços domésticos e mecanismos

Annals of Museu Paulista. v. 21. n.2. Jul.-Dec. 2013. 
59. Com 18 anos, Korrodi partiu para Itália numa visita de estudo com um colega de curso. De acordo com um diário de viagem da sua autoria, patente no Arquivo Distrital de Leiria, no Verão de 1939, dá-se a última grande viagem de Ernesto e de Quitéria, que partem para Itália, a fim de se encontrar com a sua família em $\mathrm{S}$. Giulio de Orta. Passam por S. Moritz até chegarem a Zurique e pelas Baleares e Tanger, onde Ernesto participa numa excursão organizada na véspera. que visam uma maior eficácia do serviço doméstico, como o monta-pratos que facilita a circulação dos alimentos ou as campainhas eléctricas. Ao nível do aquecimento das dependências, este era sobretudo providenciado por lareiras ou fogões, solução que contrasta com a modernidade das anteriores soluções.

Por último, a Arte Nova faz-se sentir ao nível do detalhe e continuamos a vê-la relacionada com outros modelos franceses e sobretudo ingleses, em elementos isolados ou composições que exprimem a natureza verdadeiramente ecléctica da obra de Ernesto Korrodi: pormenores escultóricos, padrões da azulejaria e de papéis de parede presentes nas paredes, tectos ou lambris, nos desenhos dos tectos em caixotões ou estucados, nas curvas e contracurvas dos vãos, nas cores presentes nas molduras ou vidros texturados das portas e janelas que suscitam diferentes ambiências. Assistese à divisão da parede em várias secções horizontais e introdução de frisos lineares que contornam os planos superiores das paredes e que formam autênticas molduras desenhadas a stencil, constituídas por motivos fitomórficos mais abstractos Há que salientar o papel dos materiais ou soluções, produzidas pelas manufacturas alemãs, inglesas ou belgas, designadamente papéis de parede simples ou oleados, faianças, ladrilhos, vidros, ferragens, iluminação, técnicas de aplicação de soalhos de madeira ou loiças sanitárias cerâmicas. Algumas destas fórmulas industriais assumiam não só um papel estético mas também funcional no sentido de dar resposta a uma higienização progressiva da habitação.

A atitude de Korrodi consiste em projectar em função do seu tempo e do perfil de cada cliente, retirando do passado e do presente todas as soluções que possam dar resposta às funções pretendidas. Desconhecemos quais seriam os seus livros de cabeceira, mas sabemos que se cruzou com Raul Lino e que assinava algumas revistas internacionais, responsáveis pela publicação de projectos de autores com obras literárias determinantes, nomeadamente Baillie Scott. Revistas portuguesas de especialidade, designadamente A Architectura Portugueza (1908-1958) e A Construcção moderna (1900-1919), publicavam também projectos, entre eles alguns da autoria do próprio Korrodi, contribuindo ao mesmo tempo para a divulgação de concursos públicos, Prémios Valmor, Regulamentos, dando a conhecer aos profissionais - que se passava lá fora, por meio de artigos críticos e actas de congressos internacionais. As deslocações ao estrangeiro foram também certamente determinantes para as suas opções projectuais ${ }^{59}$. A sua obra reflecte a influência exercida por uma Art Nouveau que é cruzada com reinterpretações de fórmulas decorativas e espaciais do Renascimento, Barroco, Rococó ou medievalizantes, adivinhando-se, contudo, preocupações como a racionalidade, funcionalidade, padronização e integração de produtos industriais. Por outro lado, os pressupostos subjacentes a este e a outros projectos da autoria de Korrodi, ainda hoje estão na base da concepção na prática do design de interiores, concluindo-se que a Art Nouveau contribuiu, de modo incontornável, para a afirmação desta área, provocando mudanças no espaço que ultrapassaram a escala do elemento decorativo. 


\section{REFERÊNCIAS}

\section{FONTES IMPRESSAS}

GENCÉ, Comtesse de. Le Cabinet de toilette d'une honnête femme. Paris: P.Pancier, 1909.

GENCÉ, Condessa de. Tratado de civilidade e etiqueta. Tradução de Luiz Cardoso. Lisboa: Guimarães \& C.a, 1909.

KORRODI, Ernesto. Estudos de reconstrucção sobre o Castello de Leiria: Reconstituição graphica de um notável exemplo de construcção civil e militar portuguesa. Zurique: Instituto Polygraphico, 1898.

LINO, Raul. Casas portuguesas: apontamentos sobre o arquitectar das casas simples, $11^{\mathrm{a}} \mathrm{ed}$. Lisboa: Cotovia, 1992. [Lisboa: Valentim de Carvalho, 1941].

MUTHESIUS, Hermann. The English House. Tradução de Janet Seligman. London: Frances Lincoln Publishers, 2007. [Das English Haus. Berlim: Wasmuth, 1904].

RIS-PAQUOT, L'Art de batir, meubler et entretenir sa maison ou manière de surveiller et d'ètre soi-même. $4^{\mathrm{a}}$. ed.. Paris: Henri Laurens, 1894.

SCOTT BAILLIE, M.H. On the Choise of Simple Furniture. The Studio, Londres, v. 10, p.152157, abr. 1897.

SCOTT BAILLIE, M.H. Houses and Gardens. London: George Newnes Limited Southampton St. Strand, 1906. Disponível em http://www.archive.org/details/cu31924015400298. Acesso em: 23 abr. 2010.

VITERBO, Sousa. Dicionário histórico e documental dos arquitectos, engenheiros e construtores portugueses. V. II. Lisboa: Imprensa Nacional-Casa da Moeda, 1899.

\section{LIVROS, ARTIGOS E TESES}

CHEVAlIER, Jean; CHEERBRANDT, Alain. Dicionário dos símbolos. Tradução de Cristina Rodriguez e Artur Guerra. Lisboa: Teorema, 1994.

COSTA, Lucília Verdelho da. Ernesto Korrodi, 1889-1944: Arquitectura, ensino e restauro do património. Lisboa: Ed. Estampa, 1997.

ELEB, Monique; DEBARRE, Anne. L'Invention de l' habitation moderne: Paris 1880-1914. Bruxelles: A.A.M., 1995.

FERNANDES, Maria João Rocha Simões. Francisco da Silva Rocha (1864-1957): arquitectura arte nova, uma primavera eterna. Tese (Mestrado) - Faculdade de Ciências Sociais e Humanas da Universidade Nova de Lisboa, Lisboa, 1985.

KINCHIN, Juliet. Interiors: Nineteenth-Century Essays on the "Masculine" and the "Feminine" Room. In: TAYLOR, Mark; PRESTON, Julieanna (ed.). Intimus Space: Interior Design Theory Reader. 2a ed.. West Sussex: John Wiley \& Sons Ltd., 2008.

MACCARTHY, Fiona. The Aesthetic Movement. The Guardian, Londres, 26 mar. 2011. 
MADSEN, S.Tschudis. Art Nouveau. Tradução de Ângelo de Sousa. Porto: ED.Inova, 1967.

OLIVEIRA, Maria Genoveva Moreira. Rota de arquitectura Korrodi: contributo para o conhecimento da vida e obra do arquitecto (1870-1944). Dissertação (Mestrado) - Faculdade de Letras da Universidade de Lisboa, Lisboa, 2005.

PEDREIRINHO, José Manuel. Dicionário dos arquitectos activos em Portugal do século I à actualidade. Porto: Edições Afrontamento, 1994.

PRAZ, Mario. An Illustrated History of Interior Decoration from Pompeii to Art Nouveau. 3a ed. New York: Thames \& Hudson Inc., 2008.

ROBINSON, Joyce Henry. Hi Honey, I'm Home. In: TAYLOR, Mark; PRESTON, Julieanna (ed.). Intimus Space: Interior Design Theory Reader. 2a ed.. West Sussex: John Wiley \& Sons Ltd., 2008.

ROMÃOZINHO, Ana Mónica Romãozinho. Design de interiores domésticos no início do século XX: Apontamentos de Arte Nova na obra de Ernesto Korrodi. Tese (Doutoramento) Faculdade de Arquitectura da Universidade Técnica de Lisboa, Lisboa, 2013.

SANTOS, Rui Afonso. O design e a decoração em Portugal, 1900-1994. In: PEREIRA, Paulo (dir.). História da arte portuguesa, do barroco à contemporaneidade, v.III. Barcelona: Círculo de Leitores, 1995.

THORNON, Peter. L'époque et son style. Tradução de Jean-François Allain. Paris: Flammarion, 1986.

\section{SÍTIOS}

Câmara Municipal da Covilhã. Disponível em: http://www.cm-covilha.pt/simples/?f=2395. Acesso em: 15 maio 2011.

Ebay. http://cgi.ebay.com.sg/ORIGINAL-ANTIQUE-Art-Nouveau-Majolica-tile-150-PCS/220684921022?pt=Architectural_Garden\&hash=item3361d8a8be. Acesso em: 11 ago. 2011.

Matin Lumineux. Disponível em: http://matinlumineux.blogspot.com/2011/08/art-nouveau. html. Acesso em: 11 ago. 2011.

The Antique Floor Company. Disponível em: http://www.theantiquefloorcompany.com. Acesso em: 11 ago. 2011.

Artigo apresentado em 04/05/2012. Aprovado em 19/07/2013. 